\title{
ANSELMO DE CANTUÁRIA SOBRE A VERDADE DO PENSAMENTO
}

\author{
Roberto Hofmeister Pich
}

PUCRS

\begin{abstract}
This article develops the hypothesis that Anselm's doctrine of truth is illuminating in a decisive way to understand correctly the argument for the existence of God in Proslogion. Departing from a basic interpretation of the unum argumentum and after explaining basicaly the main aspects of the dialogue De veritate, the "truth of thought" is investigated in particular. At the end, the analysis and the comparison of the senses of cogitare and cogitatio, in Proslogion and in the work De veritate, show to be useful both to clarify central elements of the argument and to better understand what Anselm really wanted to say in De veritate by taking cogitatio as a kind of truth bearer.
\end{abstract}

Keywords: Anselm of Canterbury, argument for the existence of God, thought, truth, Proslogion, De veritate.

Resumo: Este artigo desenvolve a hipótese de que a doutrina anselmiana da verdade é esclarecedora de modo decisivo para bem compreender o seu argumento a favor da existência de Deus no Proslogion. Partindo de uma interpretação básica do unum argumentum, e após expor de forma resumida os principais aspectos do diálogo De veritate, procura-se investigar em especial a "verdade do pensamento". Ao final, a análise e a comparação dos sentidos de cogitare e de cogitatio, no Proslogion e na obra De veritate, mostram ser úteis tanto para elucidar elementos centrais do argumento quanto para melhor entender o que Anselmo, no De veritate, efetivamente quis dizer ao tematizar a cogitatio como um tipo de portador de verdade.

Palavras-chave: Anselmo de Cantuária, prova da existência de Deus, pensamento, verdade, Proslogion, De veritate. 


\section{Introdução}

A presente investigação sobre o conceito de verdade desenvolvido por Anselmo de Cantuária (1033-1109), em seu tratado homônimo De veritate (ca. 1080-1085), não deve ser vista como um interesse de pesquisa isolado. Ela parte da hipótese de que a noção anselmiana de verdade pode ser esclarecedora para o seu argumento para mostrar a existência de Deus no summum opusculum chamado Proslogion (1078). A conexão entre as duas matérias - prova da existência de Deus e teoria da verdade - ou de maneira mais geral entre os dois escritos - Proslogion e De veritate - não é óbvia. Ela será esboçada - e não mais do que esboçada ${ }^{1}$ - em primeiro lugar (I.), após um resumo de convicções acerca do argumento. Em seguida, entro no tema da verdade no pensamento de Anselmo, sugerindo uma exposição básica e pouco original sobre o mesmo (II.), mas que já insinua os paralelos que tendem a ser mais importantes para a prova no Proslogion. Em terceiro lugar, (III.) detalho a "verdade do pensamento" de acordo com Anselmo, com pretensões de originalidade: sobre um dos mais breves e menos estudados capítulos do De veritate pretendo fazer sugestões de interpretação inovadoras e, ao mesmo tempo, consistentes com níveis de discurso essenciais ao unum argumentum (IV. Observações finais). Em parte, são justamente esses níveis de discurso essenciais ao argumento de Anselmo que forçam uma releitura de De veritate III e, por certo, demais capítulos.

\section{A "ideia de Anselmo" e o "argumento de Anselmo" (ratio Anselm): um esboço}

Embora seja um empreendimento inglório buscar expressar algo novo sobre a básica estrutura e o fundamental objetivo de Anselmo no seu argumento a favor da existência de Deus em Proslogion II-IV, podem haver modestas e recompensadoras surpresas ao estudá-lo a novo e ao esforçar-se em deixar que ele mesmo se apresente: existem níveis essenciais na argumentação que podem ser detectados e mantidos como pedras angulares

\footnotetext{
1 Com efeito, por privilegiar as Partes II e III deste estudo, na Parte I deixarei de lado a literatura secundária especializada. A Parte I será em breve desenvolvida em detalhes e em um texto muito mais extenso, que se encontra em preparação.
} 
do edifício interpretativo maior. De início, (1) creio irrecusável a afirmação de que, metodologicamente, o próprio Anselmo vê o seu procedimento dialético como uma prova (unum argumentum). A argumentação inteira no Proslogion possui basicamente duas partes, ou seja, Anselmo deseja mostrar (i) que Deus verdadeiramente existe (Deus vere est, em que "vere esse" parece significar "existir realmente" ou "existir na realidade"; Proslogion II-IV) e (ii) que Deus é o "bem supremo" (summum bonum) (Proslogion V-XXVI, embora XIV-XV tragam novamente reflexões metodológicas) ${ }^{2}$. Por certo, mostrar (i) que Deus existe envolve pelo menos parcialmente mostrar (ii) o que Deus é. Particularmente as conclusões de Proslogion III e IV enfatizam o ponto de que a procedimento dialético é uma questão de "inteligência" - intelligere -, e não de fé3. Isso foi presumido também em Proslogion I, pois Anselmo assevera ali (a) que o seu objetivo é aliquatenus intelligere veritatem tuam, e não penetrare altitudinem tuam (um ponto ratificado no Liber apologeticus IX) ${ }^{4}$, onde o propósito de intelligere é manifesto, e a veritas buscada deveria abarcar os passos (i) e (ii) adiantados no Prooemium. Além do mais, (b) o monge vê no procedimento como um todo um movimento trinitário da alma-imagem via

\footnotetext{
2 Cf. Anselmus, Proslogion prooemium (ed. SCHMITT, F. S. 1961, p. 68): “(...), si forte posset inveniri unum argumentum, quod nullo alio ad se probandum quam se solo indigeret, et solum ad astruendum quia Deus vere est, et quia est summum bonum nullo alio indigens, et quo omnia indigent ut sint et ut bene sint, et quaecumque de divina credimus substantia, sufficeret". Embora a passagem permita apontar para uma terceira intenção de prova (ou mesmo instrução) por Anselmo, isto é, "todas as [demais] coisas que cremos sobre a substância divina", parece-me mais simples incluir esse tópico dentro do segundo, respectivo ao "que é" Deus. Cf. HENDLEY, B. Anselm's Proslogion Argument, in: KLUXEN, W. (Hrsg.), Miscellanea Mediaevalia 13/2 - Sprache und Erkenntnis im Mittelalter, p. 840. Creio que a seguinte passagem reforça a minha observação, a saber, Anselmus, Proslogion II (ed. SCHMITT, 1961, p. 84): "Ergo Domine, qui das fidei intellectum, da mihi, ut quantum scis expedire, intelligam, quia es sicut credimus, et hoc es quod credimus". Cf. também SCHMITT, Einführung, in: Anselm von Canterbury, p. 20-30, 62-63.

${ }^{3}$ Cf. Anselmus, Proslogion III (ed. SCHMITT, 1961, p. 86): "Cur itaque dixit insipiens in corde suo: non est Deus, cum tam in promptu sit rationali menti te maxime omnium esse? Cur, nisi quia stultus et inspiens ?"; IV (ed. SCHMITT, 1961, p. 88): "Gratias tibi, bone Domine, gratias tibi, quia quod prius credidi te donante, iam sic intelligo te illuminante, ut, si te esse nolim credere, non possim non intelligere".

${ }^{4}$ Pode-se dizer "inefável" e "não-pensável" e assim entender algo daquela realidade que é inefável e não-pensável, ainda que dessa maneira não se possa dizer no coração ou pensar aquela realidade mesma que é inefável e não-pensável; cf. Anselmus, Liber apologeticus IX (ed. SCHMITT, 1961, p. 153): "[9.] Sed et si verum esset non posse cogitari vel intelligi illud quod maius nequit cogitari, non tamen falsum esset "quo maius cogitari nequit" cogitari posse et intelligi. Sicut enim nil prohibet dici "innefabile", licet illud dici non possit quod "innefabile" dicitur; et quemadmodum cogitari potest "non cogitabile", quamvis illud cogitari non possit, cui convenit "non cogitabile" dici: (...)".
} 
memória, inteligência e amor ${ }^{5}$. Finalmente, vista a paisagem como um todo, o argumento de Anselmo é em um sentido a priori, uma vez que ele não apela a nenhuma "experiência do mundo" (elemento esse enfatizado em Liber apologeticus V, contra o espírito empirista de Gaunilo no que diz respeito à origem de noções eidéticas na mente) ${ }^{6}$, e é em um sentido $a$ posteriori, dado que o centro da prova é a posse de uma ideia, ou, antes, são as consequências de reconhecer a posse de uma ideia única na mente - uma delas é que a ideia é por certo um efeito cuja causa deveria ser procurada ou, ao menos, é encontrada junto com ele.

(2) Em segundo lugar, ninguém pode ignorar o centro mesmo da ratio Anselmi: a "ideia" de uma essência que Anselmo encontra na mente e descreve da melhor forma que pode (ao menos em um primeiro momento) através de "aliquid quo nihil maius cogitari potest" e variações semelhantes. O argumento pressupõe alguma exposição do que significa ter "ideias" ou "pensamentos" (cogitationes) ou mais simplesmente "pensar" ou "conceber" (cogitare). Proslogion II, que oferece o argumento na sua forma básica, revela uma estrutura que (i) requer que alguém reconheça em sua mente a posse da "ideia de Anselmo" (aliquid quo... ou variações) e reconheça-a não somente como um cogitare $_{1}$, mas também como um cogitare $_{2}$ - assim Anselmo o faz, e assim também ele quer que o Insensato o faça. Proslogion III põe a ênfase na necessidade e na possibilidade de pensar corretamente sobre aquela natureza, partindo do aliquid quo... e acaba por parafrasear aquele dictum como aliquid quod non potest cogitari non esse. Proslogion IV traz novamente a distinção entre dois tipos de pensamentos, de modo que o argumento só funciona se o Insensato, como Anselmo, encontra na mente a ideia correta e pensa nela da maneira correta. Quais são essas duas formas de apreender ideias na mente? Elas aparecem em Proslogion II em torno do exemplo do pintor, ou seja, a distinção entre "aliud enim est rem esse in intellectu" ( cogitare $\left._{1}\right)$ e "aliud intelligere rem

\footnotetext{
${ }^{5}$ Cf. Anselmus, Proslogion I (ed. SCHMITT, 1961, p. 82): "Fateor, Domine, et gratias ago, quia creasti in me hanc imaginem tuam, ut tui memor te cogitem, te amem. (...). Non tento, Domine, penetrare altitudinem tuam, quia nullatenus comparo illi intellectum meum; sed desidero aliquatenus intelligere veritatem tuam, quam credit et amat cor meum".

${ }^{6}$ Cf. Anselmus, Liber apologeticus V (ed. SCHMITT, 1961, p. 150): "Nullatenus enim potest intelligi "quo maius cogitari non possit", nisi id quod solum omnibus est maius. Sicut ergo "quo maius cogitari nequit" intelligitur et est in intellectu, et ideo esse in rei veritate asseritur: sic quod maius dicitur omnibus, intelligi et esse in intellectu, et idcirco re ipsa esse ex necessitate concluditur".
} 
esse" $\left(\text { cogitare }_{2}\right)^{7}$, e mais uma vez em Proslogion IV, ao explanar-se de que maneira o Insensato poderia dizer em seu coração ou pensar "Deus não existe", após reconhecer a posse, na mente, da ideia de Anselmo. O que o Insensato disse ou pensou é somente explanável ao distinguir-se "aliter enim cogitatur res cum vox eam significans cogitatur" ( cogitare $\left._{1}\right)$ de "aliter cum id ipsum quod res est intelligitur" (cogitare $\left.)_{2}\right)^{8}$. (No Liber apologeticus VII e VIII, cogitare $_{1}$ é avaliado no sentido de "coniicere" ou "intelligere aliquo modo, non omnino", em clara oposição a "intelligere nullo modo") ".

$\mathrm{O}$ argumento - via reductionis - funciona somente se, tendo o Insensato reconhecido que possui aquela ideia na mente, ele a concebe corretamente, tal como o movimento dialético no Proslogion deveria levá-lo a fazer, ou seja, como um datum intencional de caráter único. Da posse e do reconhecimento de tal datum intencional para o vere esse ou existere in re da essência que ele nomeia a passagem é boa. Que Anselmo quer mostrar que a ideia ou o aliquid quo... é intencional em um sentido especial, isso é ilustrado pelo caso paradigmático do pintor, em Proslogion II ${ }^{10}$ : uma coisa é que o pintor pense antecipadamente em alguma pintura - por assim dizer, o quadro de uma sereia - que ele pretende pintar; nesse caso, o pintor tem

\footnotetext{
${ }^{7}$ Cf. Anselmus, Proslogion II (ed. SCHMITT, 1961, p. 84): "Aliud enim est rem esse in intellectu, alium intelligere rem esse".

${ }^{8} \mathrm{Cf}$. Anselmus, Proslogion IV (ed. SCHMITT, 1961, p. 88): “(...): non uno tantum modo dicitur aliquid in corde vel cogitatur. Aliter enim cogitatur res, cum vox eam significans cogitatur, aliter cum id ipsum quod res est intelligitur". Cf. também G. Kapriev, ... Ipsa vita et veritas. Der "ontologische Gottesbeweis" und die Ideenwelt Anselms von Canterbury, p. 207-212, 240-244.

${ }^{9}$ Cf. Anselmus, Liber apologeticus VII (ed. SCHMITT, 1961, p. 151): "Aut si aliquando negatur quod aliquatenus intelligitur, et idem est illi quod nullatenus intelligitur: nonne facilius probatur quod dubium est de illo quod in aliquo, quam de eo quod in nullo est intellectu? Quare nec credibile potest esse idcirco quemlibet negare "quo maius cogitari nequit", quod auditus aliquatenus intelligit: quia negat Deum, cuius sensum nullo modo cogitat"; VIII (ed. SCHMITT, 1961, p. 152): "Item quod dicit "quo maius cogitari nequit" secundum rem vel ex genere tibi vel ex specie notam te cogitare auditum vel in intellectu habere non posse, quoniam nec ipsam rem nosti, nec eam ex alia simili potes conicere: palam est rem aliter sese habere". De resto, poderia ser mostrado em detalhes que Anselmo no Liber apologeticus e mesmo Gaunilo em seu breve escrito trabalham decisivamente com a distinção entre cogitare e cogitare $_{2}$ e a sua aplicabilidade para o conhecimento da existência de Deus. Isso, em geral, é bem notado por J. Moreau, Logique et dialectique dans l'argument du "Proslogion", in: KLUXEN, W. (Hrsg.), Miscellanea Mediaevalia 13/2 - Sprache und Erkenntnis im Mittelalter, p. 718-721.

${ }^{10} \mathrm{Cf}$. Anselmus, Proslogion II (ed. SCHMITT, 1961, p. 84): "Nam cum pictor praecogitat quae facturus est, habet quidem in intellectu, sed nondum intelligit esse quod nondum fecit. Cum vero iam pinxit, et habet in intellectu et intelligit esse quod iam fecit". A distinção qur proponho a seguir tem semelhanças, que não podem ser exploradas neste estudo, com a distinção entre o pensar um conteúdo ou uma ideia "constitutivamente" (constitutively) e "parasiticamente" (parasitically), explorada por autores como G. KLIMA e B. DAVIES; cf. DAVIES, B. Anselm and the Ontological Argument, in: DAVIES, B. and LEFTOW, B. (eds.), The Cambridge Companion to Anselm, p. 171-176.
} 
aquela imagem ou a ideia na mente, e ela é significativa como uma palavra na mente, mas ele sabe que ela não designa coisa existente qualquer, uma vez que ele ainda não pintou o quadro. Tal ideia é pensada como a-ideia-dealguma-coisa-não-existente (é simplesmente um cogitare $_{1}$ ). Mas, é outra coisa pensar o quadro de uma sereia após tê-lo pintado; afinal, o pintor tem uma imagem na mente que é significativa, e ele também pensa através daquele pensamento existir o que ele fez. Tal ideia é agora pensada como aideia-de-alguma-coisa-existente (é um cogitare 2 ), embora não como a-ideiade-alguma-coisa-existente-necessariamente. A ideia-de-alguma-coisaexistente-necessariamente ou uma ideia que apresenta a si mesma como necessariamente intencional é o que Anselmo quer que o Insensato reconheça possuir em sua mente. Desse modo, o Insensato tem de localizar a ideia correta em sua mente como um cogitare $_{2}$ de intencionalidade única. A partir do que foi dito, Proslogion II e IV estipulam como é preciso - e devido - pensar a "ideia de Anselmo", Proslogion II e III estipulam e analisam qual é o conteúdo a conceber-se.

(3) Em terceiro lugar, cabe explorar a hipótese de que o aliquid quo..., uma vez que inclui através dos comparativos "maius" e "melius" a linguagem da perfeição, é uma pré-noção do ente perfeito (desenvolvida a partir de Proslogion V em diante). Especialmente se for posto o olhar no Liber apologeticus de Anselmo, é antes a ideia do ente absoluto que é desenvolvida na fórmula (Proslogion III e Liber apologeticus I adicionam noções de necessidade ${ }^{11}$, Liber apologeticus I e IV adicionam as noções de eternidade ou carência de começo e fim, de ser uma totalidade ilimitada de presença, dando eco ao conceito de infinitude ${ }^{12}$ ). De qualquer maneira, deve ser apontado que, se é com a fórmula aliquid quo nihil maius cogitari potest e pequenas variações que Anselmo começa o movimento dialético, ele admite que ela pode ser modificada ou parafraseada para expressar o mesmo (absoluto), na medida em que as paráfrases atuam para ajudar o

\footnotetext{
11 Cf. Anselmus, Proslogion III (ed. SCHMITT, 1961, p. 86): "Quod utique sic vere est, ut nec cogitari possit non esse. Nam potest cogitari esse aliquid, quod non possit cogitari non esse; quod maius est quam quod non esse cogitari potest"; Liber apologeticus I (ed. SCHMITT, 1961, p. 144-145): "(...): certe ego dico: si vel cogitari potest esse necesse est illud esse. Nam "quo maius cogitari nequit" non potest cogitari esse nisi sine initio. Quidquid autem potest cogitari esse et non est, per initium potest cogitari esse. Non ergo "quo maius cogitari nequit" cogitari potest esse et non est. Si ergo cogitari potest esse, ex necessitate est".

12 Cf. Anselmus, Liber apologeticus I (ed. SCHMITT, 1961, p. 144-145), nota anterior; IV (ed. SCHMITT, 1961, p. 148): "Illud vero solum non potest cogitari non esse, in quo nec initium nec finem nec partium coniunctionem, et quod non nisi semper et ubique totum ulla invenit cogitatio".
} 
Insensato a localizar a ideia correta da essência designada - uma ideia que, como uma armadilha, prende o cogitante dentro de uma intencionalidade única. Dado que Anselmo quer que o Insensato reconheça a ideia fundante do aliquid quo..., ele modifica a formulação em Proslogion III para (o que corresponderia propriamente a) aliquid quod non potest cogitari non esse, noção essa a partir da qual não é surpreendente encontrar no Liber apologeticus (I e IV, por exemplo) noções de um ente necessário. Aquela nova concepção - a partir de Proslogion III - inclui necessidade, mas ela não inclui a existência ou a existência necessária como um predicado, uma reivindicação que não aparece em lugar algum em Anselmo, tampouco em Proslogion V, onde a primeira perfeição deduzida é existire per se ipsum ou independência ontológica ${ }^{13}$. (Anselmo faz uso, com efeito, em Proslogion III de "habes esse", mas ali a expressão significa claramente "existir"14). Se uma paráfrase correta para aliquid quod non potest cogitari non esse seria aliquid quod est ex necessitate, nesse caso a necessidade é antes um modo de ser do pensável máximo, e como um modo de ser da coisa concebida uma vez que a ideia não é meramente um pensável máximo, mas um pensável máximo capaz de um cogitare $_{2}-$, a necessidade é um aspecto da intencionalidade única daquela ideia. De acordo com isso, Proslogion II e III não oferecem margem alguma para algo como um "segundo argumento ontológico". Afinal de contas, a conclusão é nos dois capítulos a mesma "Deus verdadeiramente existe" -, e é tão somente o caso que nas premissas o sumo pensável é formulado diferentemente ${ }^{15}$.

(4) Finalmente, tendo sugerido a estrutura essencial do raciocínio dialético conduzido por Anselmo, é possível propor uma forma lógica simples ao argumento: (Premissa ${ }_{1}$ ): Há na mente a ideia do máximo pensável (ou: Há na mente a ideia "aliquid quo nihil maius cogitari potest”, ou variações discutidas tais como Há na mente a ideia "aliquid quod non potest cogitari non esse”, etc.); (Premissa ${ }_{2}$ ) Aquela ideia na mente é tanto significativa (cogitare ${ }_{1}$ ) quanto verdadeira e intencional (de uma maneira única) (cogitare 2 ); (Conclusão) $\mathrm{O}$ ente absoluto (a essência apontada intencionalmente, e intencionalmente com necessidade, pela ideia) existe

\footnotetext{
${ }^{13}$ Cf. Anselmus, Proslogion V (ed. SCHMITT, 1961, p. 90): "Sed quid es, nisi id quod summum omnium solum existens per seipsum, omnia talia fecit de nihilo?".

${ }^{14}$ Cf. Anselmus, Proslogion III (ed. SCHMITT, 1961, p. 86): "Solus igitur verissime omnium et ideo maxime omnium habes esse".

${ }^{15}$ Cf. também SCHÖNBERGER, R. Anselm von Canterbury, p. 82-85.
} 
em realidade. No intuito de melhor entender a passagem daquelas premissas explícitas por Anselmo para a conclusão, pode-se oferecer um argumento posterior a ser tomado ad mentem Anselmi. (Premissa maior): De tudo o que é um conteúdo inteligível e verdadeiro (ou: intencional) na mente tem de existir ou tem de ter existido a coisa mesma que fundamenta tal conteúdo (com ou sem qualquer prova posterior a posteriori desde o efeito como um datum noético até a causa como razão formal); (Premisa menor): Existe na mente o conteúdo pensável máximo ${ }^{16}$ e verdadeiro de maneira única; (Conclusão): Do conteúdo pensável máximo e verdadeiro de maneira única na mente tem de existir a coisa que dá fundamento àquele conteúdo.

De fato, embora seja certo que Anselmo em momento algum julgou necessário (ou teoricamente imanente ao seu argumento) justificar a intencionalidade especial da "ideia de Deus" em torno da qual o dialético leva o Insensato a contradizer-se e (alegadamente) ser forçado a reconhecer a existência do máximo pensável, é justo perguntar se a teoria do significado de cogitationes à qual a tese da intencionalidade está acoplada pode ser substanciada. Em especial, se há um explícito objetivo, no Proslogion, de "entender" (intelligere) de algum modo a "verdade" de Deus e se esse propósito passa pelo conhecimento de que "Deus existe em realidade [ou: verdadeiramente, vere]" 17 , parece haver no Proslogion uma vinculação espontânea entre o ser verdadeiro e o existir na realidade ${ }^{18}$. Não há, porém, uma reflexão bem desenvolvida no Proslogion sobre a verdade e

\footnotetext{
${ }^{16}$ Mostrar que da ideia do aliquid quo... deduz-se logicamente com necessidade que o máximo pensável qua máximo pensável existe na realidade é parte fundamental do argumento e da defesa desta premissa. Embora essa seja uma "conexão de ideias" presente no argumento e fundamental para que 0 sujeito possa certificar-se de que tem a ideia do aliquid quo..., com todas as suas implicações precisas, ela tanto não parece poder de fato ir além do círculo do pensamento ou do conceber no entendimento como é diferente da passagem, que tomo como mais importante para a ratio, do conceito "real" e "intencional" do aliquid quo..., efetivamente presente na mente do(s) sujeitos(s), para a existência na realidade da coisa concebida.

${ }_{17}$ Sem dúvida, os usos de "vere" - e "veritas" - no Proslogion que dão ensejo ao vínculo teórico ora adiantado tendem a ser direcionados para um ou outro lado, dependendo de qual chave interpretativa é adotada como método e princípio de elaboração teórica de Anselmo. Assim, pois, HOGG, D. S. Anselm of Canterbury, The Beauty of Theology, p. 91-92, pressupondo que Anselmo parte do fato da revelação e do dado da fé, assevera que ele nada busca provar da existência de Deus, mas essenciamente procura dizer algo acerca do ser e da natureza divina; por isso mesmo, cabe compreender "vere", nas (dez) vezes em que se aplica diretamente a Deus, como "certo", "com certeza" ou "certamente", em que buscar a "certeza" da existência de Deus é radicalmente diferente de buscar "provar" a sua existência. Nesses termos, 0 autor segue as acepções basilares da obra de BARTH, K., Fides quaerens intellectum. Anselms Beweis der Existenz Gottes im Zusammenhang seines theologischen Programms, 1931.

18 Na discussão com Gaunilo, ela é espontânea e até mesmo mais explícita.
} 
o cogitare próprio ao qual o dialético deseja conduzir o Insensato, portanto, entre verdade e pensamento (verdadeiro), portanto, entre verdade e conhecimento da verdade pela via do pensamento portador da verdade. Se for possível estabelecer ou sugerir essa relação a partir do diálogo De veritate, ela será ao mesmo tempo de auxílio para associar (i) existir na realidade, (ii) pensamento verdadeiro e conhecimento da verdade mais (iii) o pensamento intencional - que, em minha leitura ao menos, consiste na estratégia central da ratio Anselmi. Em outras palavras, o vínculo entre (i) o ser verdadeiro e o existir na realidade com (ii) o pensamento verdadeiro e conhecimento da verdade poderá ajudar a estabelecer o vínculo entre (iii) pensamento e intencionalidade, que se salienta decisivamente no argumento único do Proslogion. Em especial, pois, a investigação que se segue acerca da concepção anselmiana de verdade, enquanto formula a sua estrutura fundamental, concentra-se na "verdade dos enunciados" e, mais ainda, na "verdade do pensamento".

Ainda uma observação prévia é bem vinda. Naturalmente, a proposta teórica de associar o unum argumentum no Proslogion a uma consideração sobre a verdade não é nova - ainda que eu creia que as ênfases de comparação que ofereço sejam originais ${ }^{19}$. Independentemente de, neste estudo, eu poder justificar uma adoção significativa da linha de interpretação da ratio Anselmi que A. C. McGill apresentou como partindo da ideia de Anselmo enquanto "dado noético"20, o vínculo que procuro foi buscado por precursores que se associam a essa interpretação. A interpretação parte da percepção de que o argumento se centra na tese de que o insensato "entende" a ideia de Anselmo. A ideia, nesse caso, não é uma entidade, mas um conceito especial e está no entendimento. À realidade, pois, é preciso chegar partindo da consciência que a mente possui ou pode possuir desse conteúdo imanente - como também de outros. Sob algum aspecto - e aqui não partilho de muitos dos encaminhamentos de prova por parte dos autores que podem ser associados a essa linha

\footnotetext{
${ }_{19}$ Nesse sentido, o estudo de POUCHET, R. La rectitudo chez Saint Anselme, Un itinéraire Augustinien de l'ame à Dieu, p. 67-83, foi uma grata descoberta, e será citado no seguimento deste trabalho. Alerto porém que Pouchet adota uma interpretação que faz do "conhecimento religioso", após a fé e com a fé, um conhecimento "reto" e, como depreender-se-ia de Proslogion I, condicionante do pensar verdadeiro. Mais recentemente, a leitura referencial parece-me ser G. Kapriev, op. cit., 1998.

${ }^{20}$ Cf. MCGILL, A C. Recent Discussions of Anselm's Argument, in: HICK, J.and MCGILL, A. C. (eds.), The Many-Faced Argument, Recent Studies on the Ontological Argument for the Existence of God, p. 7983.
} 
interpretativa -, Deus tem de ser entendido e conhecido, como existente, na qualidade de "causa" dos "dados psicológicos", dos quais, incluindo a necessidade lógica, tem-se uma consciência única e avassaladora. Nesse espaço, o caráter "ontológico" ou a priori do argumento, que parece ganhar a existência de Deus só a partir da ideia do sumo inteligível que habita o pensamento, confunde-se com o caráter "cosmológico", pois parte-de de um "dado contingente", uma idéia ou um datum na mente, que daí aponta para a existência de Deus como a sua única causa possível ${ }^{21}$.

Dentro da "doxografia" elaborada por A. C. McGill acerca dessa tese - da qual omito a maioria dos nomes e as reconstruções do argumento -, há destaque para a abordagem (fragmentada, porém sutil) de Étienne Gilson. Para É. Gilson, Anselmo apelaria à realidade de Deus - que ele identifica com "ser" (em sentido absoluto) 22 - como a causa, não do datum inicial, mas antes da "necessidade lógica" descoberta pela mente ao analisar aquela ideia. Consciente de que esse não é o modo como Anselmo efetivamente apresenta a sua prova, Gilson anota que o que Anselmo em si consegue demonstrar é que o pensamento da não-existência de Deus (a negação da consequência lógica de pensar a ideia de Anselmo) é impossível a uma mente racional. Anselmo, na letra, move-se da necessidade lógica revelada na ideia "imediatamente para a conclusão de que Deus deve existir na realidade objetiva". Crítico ao ponto a que chega a exposição literal do argumento por Anselmo, Gilson assevera que só se pode escapar ao julgamento de que o argumento é vazio de significado ao inseri-lo dentro "de uma doutrina da verdade", de acordo com a qual "a necessidade lógica de afirmar a existência de alguma coisa só pode ser causada por e é, portanto, um sinal infalível da realidade ôntica daquele coisa". Na forma mais geral de estabelecer a necessidade de uma afirmação de existência (ou qualquer outra), a teoria da verdade teria de rezar que "toda proposição logicamente necessária é verdadeira" porque esse mesmo conteúdo é "causado pela realidade a que ela se refere". No relato - ou em um dos relatos - de É. Gilson, esse princípio de atribuição de verdade seria

\footnotetext{
21 Id. ibid., p. 79.

${ }^{22}$ Cf. GILSON, É.The Spirit of Mediaeval Philosophy, p. 59; idem, La philosophie au Moyen Age, Des origines patristiques a la fin du XIVe siècle, p. 246.
} 
justamente desenvolvido por Anselmo em De veritate II $^{23}$. Isso, ao mesmo tempo, serve para É. Gilson como um motivo para classificar o argumento proposto por Anselmo como insatisfatório, ou melhor, como um argumento que, longe de ter oferecido uma prova dedutiva por analisar a necessidade de existir a partir da "ideia de Deus", limita-se a apresentar "o datum para um prova", a saber, a base para uma "indução". A boa estratégia, nesse caso, seria a de mostrar que a necessidade de pôr a existência de Deus, a partir da análise da "ideia", "postula a existência [necessária] de Deus como a sua única razão suficiente" 24 . Eventualmente, seria justo afirmar que Anselmo só pode considerá-lo satisfatório porque, como pano de fundo ao mesmo, conta a silentio "com uma teoria causal da verdade que toma por garantida" e à qual dá voz poucos anos depois, no diálogo De veritate ${ }^{25}$. Nesses termos, pois, "a necessidade da existência de Deus é a causa da necessidade de afirmar aquela existência" - porque ela é a causa daquela proposição logicamente necessária, revelada ao pensamento ao assumir-se as consequências totais de pensar a ideia de Anselmo ${ }^{26}$. É. Gilson reconhece, como também reconhecerei nas Considerações Finais deste estudo, que Anselmo em momento algum parece crer que demonstrar a existência de Deus tem de consistir "em mostrar como essa necessidade causa a necessidade de nós afirmarmos a sua existência" - o que possivelmente condena o argumento a uma base frágil e a uma força diminuta: Anselmo simplesmente colocaria a existência de Deus como necessária em si, "porque ela é necessária ao pensamento" 27.

Ainda que eu partilhe da concepção de que a "ideia" ou o "aliquid quo..." seja exposto por Anselmo como um dado noético e que o seu estatuto qua ideia, incluindo a fundamentação das consequências de sua

\footnotetext{
${ }^{23}$ Cf. McGILL, A. C., Recent Discussions of Anselm's Argument, in: HICK, J. and McGILL, A. C. (eds.), op. cit., p. 81; 0 autor cita GILSON, É., Sens et nature de l'argument de S. Anselme, in: Archives de l'histoire doctrinale et litteraire du moyen age, p. 9s., p. 13s.

${ }^{24}$ Cf. GILSON, É., The Spirit of Mediaeval Philosophy, p. 60.

${ }_{25}$ GILSON, É., id. ibid., p. 62, acredita que a construção de uma ontologia a partir do "conteúdo objetivo dos conceitos", com base em que provar-se-ia a existência de Deus por uma via indutiva na qualidade de "única causa concebível da idéia de Deus em nós", foi um caminho aberto, para os medievais, por Agostinho e pelo Anselmo do De veritate.

${ }^{26}$ Por certo GILSON, É. tem em mente algo como "Aquilo acima do qual nada maior pode ser pensado tem, com necessidade lógica, de ser pensado como existindo na realidade".

${ }^{27}$ Cf. McGILL, A. C., Recent Discussions of Anselm's Arguments, in: HICK, J. and McGILL, A. C. (eds.), op. cit., p. 81, citando novamente GILSON, É., Sens et nature de l'argument de S. Anselme, op. cit., p. $17 \mathrm{~s}$.
} 
análise, devam ser buscadas em uma teoria da verdade, não partilho por completo do entendimento que É. Gilson expressa sobre a estrutura da prova e os termos mais específicos de uma teoria causal e da verdade que está ou deveria estar na base dela. Em boa medida, vejo que falta na abordagem de É. Gilson a percepção de que a "ideia" não é simplesmente o que é pensado ou concebido pela mente racional como uma entidade própria, mas é, quando "inteligida" - como notou também A. C. McGill "fase intencional" da atividade humana ${ }^{28}$. O que deve, ao que tudo indica, ser procurado na teoria anselmiana da verdade é justamente uma maneira de compreender e justificar a intencionalidade da "ideia de Anselmo". O significado mesmo do pensamento especial e único, ou seja, o sentido do intelligere insistentemente solicitado com respeito ao aliquid quo nihil maius cogitari potest, é o item de prova a ser substanciado o quanto for possível através da leitura do De veritate.

\section{A teoria anselmiana da verdade}

O diálogo De veritate (c. 1080-1085) é o primeiro de uma trilogia metodologicamente marcada por "teologia especulativa" e filosofia em uma relação que prefigura o "método escolástico", muito embora Anselmo trate os diálogos como material teológico e que tem em vista a compreensão da Escritura Sagrada ${ }^{29}$. Mais estreitamente, De veritate tem também um vínculo sistemático com os diálogos De libertate arbitrii (c. 1080-1085) e De casu diaboli (c. 1085-1090), a saber, justamente através da noção de "retidão" (rectitudo) $)^{30}$. Em específico, é reconhecido que Anselmo, no De

${ }^{28}$ Cf. McGILL, A. C., Recent Discussions of Anselm's Arguments, in: HICK, J. and McGILL, A. C. (eds.), op. cit., p. 82.

${ }^{29}$ Cf. SCHMITT, Einführung, in: Anselm von Canterbury, De veritate - Über die Wahrheit, p. 8-9, e também HOPKINS, J. and RICHARDSON, H., Introduction, in: Anselm of Canterbury, Truth, Freedom, and Evil, Three Philosophical Dialogues, p. 10-11. Tendo em vista as ênfases internas de conteúdo (teológico), G. Colombo, Invito al pensiero di Santo Anselmo, p. 67, entende que aqueles três "tratados dogmáticos" têm como foco o tema da liberdade.

30 Os três tratados, junto com o De grammatico (c. 1080-1085), recebem um prefácio comum; todos têm a forma de diálogos entre um "mestre" e um "discípulo"; diferentemente dos demais, o De grammatico "está voltado unicamente a uma questão técnica, sobre a qual os manuais clássicos de gramática e lógica diferem: "gramático" (grammaticus, no sentido de "letrado", "especialista na língua") denota uma substância ou uma qualidade?". Cf. EVANS, G. R. , Anselm's Life, Works, and Immediate Influence, in: DAVIES, B.and LEFTOW, B.(eds.), The Cambridge Companion to Anselm, p. 14. Cf. também HOPKINS, J., Anselm of Canterbury (1033-1109), in: CRAIG, E. (ed.), The Routledge Encyclopedia of Philosophy, p. 289-290. Nesse contexto de diálogos, é curioso notar que a noção de verdade não desempenha qualquer papel no De grammatico, em realidade um estudo geral sobre a "paronimia" (e inspirado antes 
veritate, busca uma definição geral da verdade, uma definição que alega ter procurado em vão em outros escritos seus ${ }^{31}$ e que, ao final, reza assim: "a verdade é uma retidão perceptível à mente somente”. A definição só é alcançada após o exame de tipos de verdade, dado o reconhecimento de que a verdade se encontra em domínios diversos, que são tratados supostamente como partindo do mais conhecido ao mais ignorado 32 : (i) de enunciados, de (ii) pensamentos, (iii) de atos da vontade, (iv) dos sentidos e (v) da essência das coisas ${ }^{33}$.

Como análise exemplar para os demais casos, é conveniente expor o primeiro tipo, (i) a "verdade da significação" (veritas significationis) ou "verdade na enunciação" (veritas in enuntiatione), que aparece em dois aspectos básicos, um expressando cumprimento de norma e finalidade, outro expressando a forma de realização de significado. No primeiro aspecto, um "enunciado" ou uma "enunciação" (enuntiatio) ${ }^{34}$ é verdadeiro quando significa uma realidade "como deve" significá-la; é falso quando significa uma realidade "como não deve significá-la" 35 . Além disso, no segundo aspecto, a verdade de um enunciado pode ser "natural" $\mathrm{e}$ "imutável”, quando não é modificada se a coisa mesma dita se modifica, e "acidental", quando é modificada (da verdade para a falsidade), em se

nas Categorias do que no $D a$ interpretação, de Aristóteles). Mesmo onde ela fosse teoricamente considerável na proposta daquela obra, "verdade" responderia antes a interesses de análise de certos elementos linguísticos em sentenças, quando semanticamente determinadas por um sentido de re ou um sentido de dicto; cf. D. P. Henry, The Logic of Saint Anselm, p. 72-73, 84-85.

${ }^{31}$ Anselmo, cf. também DAVIES, B.and EVANS, G. R. , Introduction, in: Anselm of Canterbury, The Major Works, p. Xv, e POUCHET, R., op. cit., p. 59-60, menciona que o tratamento do assunto se deveu a uma lacuna de explanação deixada pelo Monologion, a saber, que Deus é a verdade (Jo 14.6), e essa lacuna é, no início do De veritate, lembrada pelo discípulo interlocutor; cf. Anselmus, De veritate I (ed. SCHMITT, 1966, p. 36): "D. - Quoniam Deum veritatem esse credimus, et veritatem in multis aliis dicimus esse, vellem scire, an ubicumque veritas dicitur, Deum eam esse fateri debeamus. Nam tu quoque in Monologio tuo per veritatem orationis probas summam veritatem non habere rincipium vel finem, dicens: (...). Haec tu in Monologio tuo. Quapropter veritatis definitionem a te discere exspecto".

${ }^{32}$ Cf. Anselmus, De veritate IX (ed. SCHMITT, 1966, p. 66): "Sed redeamus ad veritatem significationis, a qua ideo incepi, ut te a notioribus ad ignotiora perducerem".

${ }^{33}$ Cf. HOPKINS, J., Anselm of Canterbury (1033-1109), in: CRAIG, E. (ed.), op. cit., p. 290.

${ }^{34}$ Se é verdade que "enuntiatio" é um termo "elástico" em significado, no latim e na tradução para o inglês, assim o é também na tradução para a língua portuguesa. Reconhecendo a vagueza de seu significado e uso em Anselmo, P. King, Anselm's Philosophy of Language, in: DAVIES, B.and LEFTOW, B.(eds.), The Cambridge Companion to Anselm, p. 101, anota que o significado preferido é mesmo o de "enunciado" ou "enunciação atual" (utterance, actual utterance), de maneira que, assim como abaixo será explicitado, constitui um traço distinto das orationes e enuntiationes "a sua posse de valor de verdade".

${ }^{35} \mathrm{Cf}$. BOEHNER, Ph. et E. Gilson, História da filosofia cristã. Desde as origens até Nicolau de Cusa, p. 258. 
dando uma modificação na(s) coisas(s) enunciada(s) ${ }^{36}$. Em De veritate II, esse segundo caso do segundo aspecto básico é o que está em destaque. Se, no primeiro caso, um enunciado mantém a finalidade natural pela qual foi estabelecido (por Deus), mesmo quando não diz ou representa com exatidão o que é o caso ou o que não é o caso no mundo, isso equivale a dizer que conserva o poder de significar algo "absolutamente falando" (simpliciter), a saber, pelo simples fato de ser, desde os termos, um enunciado significativo ${ }^{37}$. Famosamente, o enunciado "É dia" (Dies est) significa por natureza que "é dia", e essa significação, que como tal todo ente capaz de linguagem compreende ou pode compreender pelas palavras mesmas, em um sentido fundamental não tem nenhuma relação com o fato de, no momento da enunciação, ser dia ou não. Cabe notar, pois, que há tanto a "significação" de um enunciado em si (sempre verdadeira ${ }^{38}$ porque há uma significatio, uma "proposição" ou um "pensamento" determinado em sua inteligibilidade) quanto a "significação" de um enunciado levando em conta a sua relação com a(s) coisa(s) enunciada(s) (podendo essa ser verdadeira, mas também ser falsa, quase a modo de uma prototeoria da suppositio ${ }^{39}$.

É justo com relação a Anselmo falar, aqui, efetivamente de "enunciado", "juízo" ou "oração falada", visto que pouco utiliza a expressão "proposição" (propositio) ao longo de De veritate. A ênfase da verdade da

\footnotetext{
${ }^{36} \mathrm{Cf}$. também a nota 1 (em pé de página), na edição espanhola, De veritate II (ed. BAC: 493-495).

${ }^{37}$ Cf. De veritate II (ed. SCHMITT, 1966, p. 44): "De illa igitur veritate, quam habet oratio secundum quod aliquis ea recte utitur, incepimus quaerere, quoniam secundum hanc veram eam iudicat usus communis locutionis. De illa autem veritate, quam non habere non potest, postea dicimus". Cf. também De veritate V (ed. SCHMITT, 1966, p. 48-52). VISSER, S. e WILLIAMS, Th., Anselm on Truth, in: DAVIES, B. and LEFTOW, B.(eds.), The Cambridge Companion to Anselm, p. 206, falam respectivamente de "retidão natural" e "retidão acidental".

${ }^{38}$ Ao menos enquanto existir a linguagem, a significação da proposição em si, sem aplicação à realidade, sempre é correta e nunca falsa. Cf. De veritate II (ed. SCHMITT, 1966, p. 42-44): "M. - Alia igitur est rectitudo et veritas enuntiationis, quia significat ad quod significandum facta est; alia vero, quia significat quod accepit significare. Quippe ista immutabilis est ipsi orationi, illa vero mutabilis. Hanc namque semper habet, illam vero non semper. Istam enim naturaliter habet, illam vero accidentaliter et secundum usum. Nam cum dico: 'dies est', ad significandum esse quod est, recte utor huius orationis significatione, quia ad hoc facta est; et ideo tunc recte dicitur significare. Cum vero eadem oratione significo esse quod non est, non ea recte utor, quia non ad hoc facta est; et idcirco non recta tunc eius significatio dicitur. Quamvis in quibusdam enuntiationibus inseparabiles sint istae duae rectitudines seu veritates; ut cum dicimus: 'homo animal est', aut: 'homo lapis non est'. Semper enim haec affirmatio significat esse quod est, et haec negatio non esse quod non est; nec illa possumus uti ad significandum esse quod non est - semper enim homo animal est -, nec ista ad significandum non esse quod est, quia homo nunquam lapis est".

39 Cf. BOEHNER, Ph. et E. Gilson, op. cit., p. 258; HOPKINS, J., A Companion to the Study of St. Anselm, p. 135-136.
} 
significação reside toda em enunciados expressos ou comunicados de uma linguagem natural - e não há nenhuma ênfase ou transição sistemática para um discurso sobre proposições mentais, ainda que tudo o que é dito sobre tal verdade das orações faladas pudesse ser dito de proposições mentais ${ }^{40}$. Fixando-se a atenção na significação corriqueira (acidental) de enunciados, o que é, pois, um enunciado? "Enunciado" ou "juízo" é uma oração falada que designa ou significa algo respectivo ao mundo. Essa oração é um sinal e, como sinal ou em virtude de sua natureza como sinal, ela significa aquilo para cuja significação foi criada. Em cumprindo essa "finalidade" constitutiva de significação, a oração ou o juízo é verdadeiro; em não cumprindo tal "finalidade", ele é falso. Levando isso em conta, uma oração enunciada afirmativa como "É dia" "deve" significar precisamente o que nela se supõe, ou seja, que é realmente dia $^{41}$. Significando o que nela se supõe ao afirmar a realidade ou ao negar a realidade, e de fato sendo o caso (a realidade) ou não sendo o caso (a realidade), o enunciado afirmativo ou o negativo, respectivamente, é verdadeiro. Do contrário, ele é falso. Assim, o enunciado tem "retidão" (rectitudo) ou "verdade" (veritas) porque cumpriu o que - ou a função que - por natureza deveria desempenhar.

Assim, pois, ainda que Anselmo, ao tratar da rectituto e da veritas de uma enunciação, enfatize em particular que é uma enunciação afirmativa que cumpre duplamente (i) a meta de significar o que existe e (ii) em geral de fazer aquilo para o que foi feita, é justo dizer que enunciados negativos, quando dizem não ser o que não é, como os afirmativos, quando dizem ser o que é ${ }^{42}$, são verdadeiros porque "exatos" ou "retos" 43 - porque como itens

${ }^{40}$ Com correção, os editores espanhóis, cf. de De veritate II (ed. BAC: 493-494), nota 1, apontam para 0 fato de que a estrutura do discurso anselmiano, aqui, torna provável o seu conhecimento do escrito $D e$ interpretatione, de Aristóteles. Aristóteles também salienta ali o estudo semântico de afirmações e negações, de orações ou proposições enunciativas. Anselmo por certo bem conhecia os escritos $D e$ interpretatione e Categoriae, de Aristóteles, e, segundo o apontamento de HOPKINS, J. and RICHARDSON, H., Introduction, in: Anselm of Canterbury, op. cit., faz uso das distinções boecianoaristotélicas entre "sentença e proposição", "substantivo e verbo", "substância e acidente".

${ }^{41} \mathrm{Cf}$. BOEHNER, Ph. et E. Gilson, História da filosofia cristã. Desde as origens até Nicolau de Cusa, p. 258.

${ }^{42}$ Que, pois, a verdade de um enunciado (afirmativo ou negativo) consiste na reta aplicação de seu significado propriamente dito, e a sua falsidade está na aplicação incorreta, quanto ao que é ou quanto ao que não é, constitui sem dúvida uma perspectiva bastante aristotélica da verdade do discurso apofântico. SCHMITT, Einführung, in. Anselm von Canterbury, op. cit., p. 9, já alertara, porém, para as limitações de estudos (agora antigos) que sobre-enfatizaram uma interpretação "realista" ou "aristotélica" da verdade no pensamento de Anselmo; o aspecto respectivo à noção de "participação" ou "platonizante" (minha expressão) da teoria anselmiana da verdade, a ser retomado mais abaixo, foi muito bem explicitado para a pesquisa pela interpretação "transcendental-subjetiva" oferecida por K. 
complexos da linguagem natural cumprem o que devem fazer. Recentemente VISSER e WILLIAMS identificaram aqui uma forma de teoria da verdade por "dupla-correspondência": um enunciado (afirmativo ou negativo) é verdadeiro quando corresponde tanto ao modo como as coisas são ${ }^{44}$ quanto ao propósito mesmo do fazer enunciados ${ }^{45}$. A "duplacorrespondência", entretanto, vale para os demais tipos de verdade na doutrina de Anselmo. Desse modo, ficaria claro que a "correção" (rectitudo) consiste basicamente em uma noção teleológica, que se inscreve em enunciados da linguagem natural: enunciados são "corretos" quando e porque fazem justamente aquilo para o que foram feitos. Naturalmente, reveste-se de importância perguntar por quem ou pelo que foi estabelecida essa finalidade natural dos enunciados.

Antes de indicar a resposta - relativamente simples - a essa pergunta, a estrutura de uma teoria da verdade ensejada por Anselmo, como notaram VISSER e WILLIAMS, permite estipular (paradigmaticamente) para enunciados (e analogamente para demais tipos de itens "verdadeiros") uma relação "tipo-espécime" (type-token) muito particular - e que exprime o cerne da concepção anselmiana da verdade. No tipo em apreço, a relação tipo-espécime explana o aspecto de um enunciado de linguagem natural, como "É dia", ter (a) um "dever" ou "propósito" de significar e (b) ser usado para significar:

O propósito de todo enunciado-tipo é significar que o que-é é, de modo que um dado enunciado-espécime é correto

Flasch, Zum Begriff der Wahrheit bei Anselm von Canterbury, in: Philosophisches Jahrbuch, (1965), p. 322-352. Cf. também HOPKINS, J. and RICHARDSON, H., Introduction, in: Anselm of Canterbury, op. cit., p. 24-26.

${ }^{43}$ Cf. De veritate II (ed. SCHMITT, 1966, p. 42): "M. - Vera quidem non solet dici, cum significat esse quod non est; veritatem tamen et rectitudinem habet, quia facit quod debet. Sed cum significat esse quod est, dupliciter facit quod debet; quoniam significat et quod accepit significare, et ad hoc quod facta est. Sed secundum hanc rectitudinem et veritatem, qua significat esse quod est, usu recta et vera dicitur enuntiatio; non secundum illam, qua significat esse etiam quod non est. Plus enim debet propter quod accepit significationem, quam propter quod non accepit. Non enim accepit significare esse rem, cum non est, vel non esse, cum est, nisi quia non potuit illi dari tunc solummodo significare esse, quando est, vel non esse, quando non est".

${ }^{44}$ Nesse sentido entendo ser correto dizer que "o modo como as coisas são", embora não explique por que há verdade em um enunciado como "Está chovendo", causa - no caso o fato mesmo de estar chovendo - a verdade do enunciado; cf. HOPKINS, J. and RICHARDSON, H., Introduction, in: Anselm of Canterbury, op. cit., p. 14-15.

${ }^{45}$ Cf. VISSER, S. e WILLIAMS, Th., Anselm on Truth, in: DAVIES, B.and LEFTOW, B.(eds.), op. cit., p. 205. 
quando significa que o que-é é. O enunciado-espécime como tal não tem nenhum outro propósito além daquele [propósito] do tipo, pelo qual ele pode ser avaliado como correto ou incorreto, verdadeiro ou falso ${ }^{46}$.

Sendo assim, seria o caso que enunciados em uso, por exemplo o enunciar de "É dia", só tem um propósito na dependência de tipos de enunciados, por exemplo, "É dia" como enunciado significativo para dizer que o que-é é, dos quais aqueles primeiros são exemplos ou usos. A isso equivale a idéia de Anselmo de que fazer uso correto de uma dada oração enunciativa é fazer uso dela de acordo com a sua finalidade ${ }^{47}$. Ligando isso à pergunta por quem ou o que, em última análise, estabelece o propósito de enunciados significativos da linguagem ou de toda a linguagem natural, pode-se constatar que a rectitudo (teleológica) de enunciados-tipo, bem como de naturezas ou essências, foi "feita" ou "estabelecida" pela verdade suma e primeira que é Deus, "no intuito de significar o que é". Isso, sem dúvida, confere uma teleologia à linguagem natural ou aos seus enunciadostipo - o que implica que todos os "enunciados-tipo" significativos, o propósito conferido a eles de significar e o propósito derivado dos enunciados-espécime em uso são como que pré-determinados por Deus e naturalmente explanados em Deus ${ }^{48}$.

Não é preciso percorrer em detalhes toda a escala de tipos de verdade assumidos por Anselmo para ter estabelecidos os aspectos gerais centrais da teoria esboçada. Destaque-se ainda, para além da verdade (ii) de pensamentos, (iii) de atos de vontade e (iv) dos sentidos, a verdade que se encontra no ápice da escala, a saber, a (v) das essências. Em um certo aspecto, ao procurar por algo comum nos tipos listados, pode-se constatar que por detrás daqueles elementos reside a verdade mais profunda das essências existentes na Verdade Suprema, Deus mesmo, e que assim determina o que "devem ser" todas as demais "realidades" e/ou "funções

\footnotetext{
${ }^{46}$ Id. ibid., p. 207.

${ }^{47}$ Ibid. Nesses termos, tipos de proposições (enunciáveis), cf. HOPKINS, J. and RICHARDSON, H., Introduction, in: Anselm of Canterbury, op. cit., p. 16, têm "naturezas" tal como "objetos físicos".

${ }^{48}$ Se isso constitui um modelo infrutífero de "platonismo" na fundamentação da linguagem significativa e se críticas consistentes podem ser atribuídas a esse quadro teórico (para além das intenções de Anselmo), cf. VISSER, S. e WILLIAMS, Th., Anselm on Truth, in: DAVIES, B. and LEFTOW, B.(eds.), op. cit., p. 208, isso (também aqui) não será abordado.
} 
significativas" para que sejam verdadeiras ${ }^{49}$. Daí que a verdade das essências é a retidão do ser das coisas todas que concordam com a sua verdade em Deus ${ }^{50}$. Isso por certo justifica afirmar que a abordagem anselmiana sobre a verdade é profundamente teológica ou metafísica, em que, se a "centralidade de Deus como Verdade suprema" é assim aventada como explanando em definitivo a essência "veritativa" de todas as coisas, ela ao mesmo tempo desempenha o critério de "unidade" da verdade em absoluto $^{51}$. Portanto, pode-se afirmar com justiça que para Anselmo "toda verdade ou bem é Deus ou de algum modo reflete Deus; assim, pois, um ente simples provê a norma pela qual todas as pretensões de verdade devem ser julgadas" ${ }^{2}$.

A suma das concepções explanadas é que a verdade - ao menos a verdade de algo ou de algo dependente - é uma espécie de "retidão" ou "correção" (rectitudo), essa retidão é invisível e só pode ser percebida pela mente ${ }^{53}$. Boehner e Gilson afirmam que essa definição é "onicompreensiva" e, pois, "transcendental" ${ }^{4}$. Mas, ao lado disso, há que se compreender a transcendentalidade da verdade na redução desta à condição última de fato e de sentido que recebe da verdade como tal, ontológica, que não é de algo, não tem, pois, a participação ou o ser medido por algo (como por uma

${ }^{49}$ Cf. De veritate VII (ed. SCHMITT, 1966, P.58): "M. - Est igitur veritas in omnium quae sunt essentia, quia hoc sunt, quod in summa veritate sunt"; "M. - Si ergo omnia hoc sunt quod ibi sunt, sine dubio hoc sunt quod debent"; "M. - Si ergo et veritas et rectitudo idcirco sunt in rerum essentia, quia hoc sunt quod sunt in summa veritate: certum est veritatem rerum esse rectitudinem". Em uma leitura mais simples, poder-se-ia dizer que a verdade na natureza ou essência das coisas como existindo na Verdade Suprema é um outro modo de dizer que há uma correspondência entre os "objetos no mundo" e os "exemplares na mente de Deus", mas creio que a essência das coisas, nas quais se inscreve a verdade, não precisa reduzir-se ao que há no mundo, pois poder-se-ia pensar em essências que têm uma verdade e não são "objetos no mundo"; cf. HOPKINS, J. and RICHARDSON, H., Introduction, in: Anselm of Canterbury, op. cit., p. 20.

${ }^{50}$ Cf. BOEHNER, Ph. et E. Gilson, op. cit., p. 259.

${ }^{51}$ Cf. VISSER, S. e WILLIAMS, Th., Anselm on Truth, in: DAVIES, B. and LEFTOW, B.(eds.), op. cit., p. 205. Cf. De veritate X (ed. SCHMITT, 1966, P.70) "M. - Considera quia, cum omnes supradictae rectitudines ideo sint rectitudines, quia illa, in quibus sunt, aut sunt aut faciunt quod debent; summa veritas non ideo est rectitudo, quia debet aliquid. Omnia enim illi debent, ipsa vero nulli quicquam debet; nec ulla ratione est quod est, nisi quia est". Cf. também De veritate XIII (ed. SCHMITT, 1966, p. 94): "M. - Amplius. Si rectitudo non est in rebus illis, quae debent rectitudinem, nisi cum sunt secundum quod debent, et hoc solum est illis rectas esse: manifestum est earum omnium unam solam esse rectitudinem".

${ }^{52}$ Cf. VISSER, S. e WILLIAMS, Th., Anselm on Truth, in: DAVIES, B.and LEFTOW, B.(eds.), op. cit., p. 205.

${ }^{53}$ Cf. De veritate XI (ed. SCHMITT, 1966, p..74): "Possumus igitur, nisi fallor, definire quia veritas est rectitudo mente sola perceptibilis".

${ }^{54} \mathrm{Cf}$. BOEHNER, Ph. et E. Gilson, op. cit., p. 260. 
causa), mas é a coisa mesma, a própria retidão, a medida suprema da verdade derivada e, nesse sentido, a verdade mesma. Por esse motivo, como um efeito ou um elemento que participa em uma causa, todos os entes diversos de Deus e todos os tipos de atividades de entes não-divinos têm de realizar, por causa da medida que é Deus e que está em Deus, aquilo que devem ser, isto é, têm uma verdade dependente da Verdade ${ }^{55}$ - ou, alternativamente, não "têm" primariamente uma verdade, mas "são" fundamentalmente na Verdade ${ }^{56}$. Assim, pois, a Verdade Suprema é o que é, não porque "devesse ser" tal como é, mas pura e simplesmente pelo fato de o ser. Sendo a medida de todas as outras verdades, inclusive a dos enunciados do passado e do futuro ${ }^{57}$, a sua própria verdade - a causa primeira ou incausada com relação aos efeitos - não se vê medir por nenhuma outra ${ }^{58}$.

Se, portanto, onde quer que a verdade seja dita ser, ela é retidão, e algo tem retidão porque está de acordo com o seu "propósito", e propósito algo ou um efeito adquire por aquilo que o causou como causa incausada, tudo o que é dito ser "verdadeiro" é verdadeiro em virtude de ser causado por Deus segundo a sua vontade. Compreende-se, pois, por que motivo é cabível uma interpetação "transcendental" (porque é onicompreensiva e redutível à condição última de sentido) e "subjetiva" (pois é explanada em última análise pela causação da vontade divina) da verdade em Anselmo de Cantuária ${ }^{59}$. Deus é a própria Verdade, porque, sem ser causada, causa ela todas as coisas e lhes designa com padrões pelos quais elas devem ser

${ }^{55}$ Cf. De veritate X (ed. SCHMITT, 1966, p. 74): "M. - Vides etiam, quomodo ista rectitudo causa sit omnium aliarum veritatum et rectitudinum, et nihil sit causa illius? D. - Video et animadverto in aliis quasdam esse tantum effecta, quasdam vero esse causas et effecta. Ut cum veritas, quae est in rerum exsistentia, sit effectum summae veritatis, ipsa quoque causa est veritatis, quae cogitationis est, et eius, quae est in propositione; et istae duae veritates nullius sunt causa veritatis. M. - Bene consideras".

56 "São" efetivamente tem o sentido, aqui, de "participam"; cf. HOPKINS, J. and RICHARDSON, H., Introduction, in: Anselm of Canterbury, op. cit., p. 17-18, 23-24. Cf. também B. Goebel, Rectitudo. Wahrheit und Freiheit bei Anselm von Canterbury, p. 45s., 217-222.

${ }^{57}$ Esses enunciados são verdadeiros, em um primeiro momento, por exprimirem um fato que foi ou que será. Uma vez, porém, que elas ou já deixaram de existir ou ainda não existem, a sua verdade não pode basear-se na realidade do seu próprio ser. Elas são verdadeiras porque existem na verdade eterna, sem a qual não seriam verdadeiras. Cf. De veritate X (ed. SCHMITT, 1966, p. 70-72).

${ }^{58}$ Cf. De veritate XIII (ed. SCHMITT, 1966, p. 94-96): "M. - Et sicut tempus per se consideratum non dicitur tempus alicuius, sed cum res quae in illo sunt consideramus, dicimus 'tempus huius vel illius rei': ita summa veritas per se subsistens nullius rei est; sed cum aliquid secundum illam est, tunc eius dicitur veritas vel rectitudo". Cf. também VISSER, S. e WILLIAMS, Th., Anselmo n Truth, in: DAVIES, B.and B, Leftow (eds.), op. cit., p. 209-210.

${ }^{59}$ Cf. novamente K. Flasch, Zum Begriff der Wahrheit bei Anselm von Canterbury, op. cit., p. 322-352. 
avaliadas. VISSER e WILLIAMS encontram, de forma feliz, na expressão "serviço próprio" ou "função própria" (proper job) a idéia de uma condição necessária (metafísico-constitutiva) para dizer que, quando itens como (i) enunciados, (ii) pensamentos, (iii) a vontade e os seus atos, (iv) os sentidos e (v) as essências, operam de tal modo que esse modo é próprio e devido, respectivo ao propósito, eles estão na e realizam a verdade ${ }^{60}$. O sentido básico geral e unitário da verdade, assim, não se dilui ${ }^{61}$. Finalmente, se Anselmo consegue assim explicar o que é algo verdadeiro, consegue explicar em definitivo por que algo é verdadeiro quando é verdadeiro, ou o que torna verdadeiro algo verdadeiro. Mais uma vez, a retidão-verdade de enunciados não reside simplesmente em estabelecer uma dada correspondência com o que é quando é, com o que não é quando não é, mas em indicar metateoricamente, em caráter transcendental, que tal e tal é a correspondência a que certas realidades ou certas atividades se prestam porque se lhes deu tal e tal função.

\section{A verdade da "opinião" ou do "pensamento"}

Tendo sido insinuada, na introdução deste estudo, a hipótese de um vínculo produtivo entre a teoria anselmiana do pensamento, em Proslogion II-IV, e a sua teoria da verdade e tendo sido proposta, em seguida, uma abordagem geral e paradigmática da concepção anselmiana da verdade em seu diálogo homônimo, sobretudo a partir dos Capítulos II, VII, X e XI, cumpre ingressar na investigação específica do Capítulo III do De veritate, em que entra em cena o segundo tipo de atividade ou realidade em que a verdade tem papel constitutivo, isto é, "a verdade da opinião" (de opinionis veritate). É o segundo mais breve capítulo daquele escrito ${ }^{62}$ e, até onde sei, é o menos considerado pela pesquisa. É oportuno, pois, que se proponha uma tradução que se supõe exata e correta:

“M. - Também dizemos que o pensamento é verdadeiro, quando é aquilo que ou bem pela razão ou de algum [outro] modo consideramos que

\footnotetext{
${ }^{60} \mathrm{Cf}$. VISSER, S. e WILLIAMS, Th., Anselm on Truth, in: DAVIES, B. and LEFTOW, B.(eds.), op. cit., p. 219; cf. HOPKINS, J. and RICHARDSON, H., Introduction, in: Anselm of Canterbury, op. cit., p. 23.

61 VISSER, S. e WILLIAMS, Th., id. ibid., p. 219-220, chamam isso de a "Grande Teoria Unificada da Verdade", segundo Anselmo de Cantuária.

${ }^{62}$ De veritate IV (De voluntatis veritate) apresenta o mesmo número de linhas, na edição de SCHMITT, 1966, p. 44-46.
} 
seja, e ele é falso quando não é [aquilo que ou bem pela razão ou de algum [outro] modo consideramos que seja].

D. - Costuma ser assim [que dizemos].

M. - O que te parece, portanto, [ser] a verdade no pensamento?

D. - Segundo o argumento que vimos sobre a proposição, nada é dito mais retamente [ser] a verdade do pensamento do que a retidão. Nesse sentido, pois, foi dado a nós poder pensar que algo é ou que não é, para que pensemos ser o que é e não ser o que não é. Por causa disso, quem considera ser o que é, considera o que deve, e por isso mesmo reto é o [seu] pensamento. Logo, se é verdadeiro e reto um pensamento não por outro motivo senão porque consideramos ser o que é, ou não ser o que não é, não é outra coisa a verdade dele senão a retidão.

M. - Raciocinas corretamente" 63 .

Antes de partir para uma análise mais estruturada, de imediato chamam a atenção o título do Capítulo III, "Da verdade da opinião" e, para o pesquisador em especial, o repetido equívoco ${ }^{64}$, por intérpretes de ontem e de hoje, talvez até mesmo motivado por esse caput ambíguo, de peremptoriamente classificar o Capítulo III como repetindo os propósitos do Capítulo II do De veritate, somente transferindo a "verdade como retidão"

${ }^{63} \mathrm{Cf}$. De veritate III (ed. SCHMITT, 1966, p. 44-46): "M. - Cogitationem quoque dicimus veram, cum est, quod aut ratione aut aliquo modo putamus esse, et falsam, cum non est. D. - Ita habet usus. M. - Quid ergo tibi videtur veritas in cogitatione? D. - Secundum rationem, quam de propositione vidimus, nihil rectius dicitur veritas cogitationis quam rectitudo eius. Ad hoc namque nobis datum est posse cogitare esse vel non esse aliquid, ut cogitemus esse quod est, et non esse quod non est. Quapropter qui putat esse quod est, putat quod debet, atque ideo recta est cogitatio. Si ergo vera est et recta cogitatio non ob aliud quam, quia putamus esse quod est, aut non esse quod non est: non est aliud eius veritas quam rectitudo. M. - Recte consideras". A tradução que proponho concorda essencialmente com a de HOPKINS, J. e RICHARDSON, H.in: Anselm of Canterbury, On Truth - De veritate, in: Anselm of Canterbury, Truth, Freedom, and Evil - Three Philosophical Dialogues, 1976, p. 81. A propósito, os dois modos ou poderes de considerar, na primeira fala (do mestre), são ou podem ser, para HOPKINS, J. and RICHARDSON, H., Notes, in: Anselm of Canterbury, Truth, Freedom, and Evil - Three Philosophical Dialogues, p. 231 (note 7), "razão" e "conjetura". Ela concorda também com a tradução de SCHMITT in: Anselm von Canterbury, De veritate - Über die Wahrheit, p. 45-47. A minha concordância estende-se também ao uso, ali, de "das Denken" para "cogitatio" ou "pensamento", uma vez que, em língua alemã, aquele vocábulo mantém certa ambiguidade, dado que cobre tanto a coisa pensada ou considerada na mente, a saber, o conteúdo ou o ser-objetivo, bem como o próprio ato de pensar, de realizar um ato mental ou o estado de ter um pensamento (de tal-e-tal conteúdo sobre algo existente ou não). Expresso o mesmo juízo com respeito à tradução de DAVIS, B. e EVANS, G. R. in: Anselm of Canterbury, On Truth, in: idem, The Major Works, p. 155-156.

${ }^{64}$ Ou ao menos a repetida precipitação: à exceção do já mencionado estudo de POUCHET, R. (nota 18), estou virtualmente sozinho na interpretação que vem a seguir. 
para um alegado domínio de enunciados e proposições mentais ${ }^{65}$. Assim, por exemplo, Visser e Williams, no capítulo "Anselm on Truth" escrito para o Cambridge Companion to Anselm, embora de resto não dediquem qualquer detalhe maior a esse ponto de discussão, tanto insistem em falar da verdade de "opiniões" como efetivamente equiparam pensamentos a enunciados ou proposições mentais ${ }^{66}$. Em uma nota de texto, os mesmos autores pedem que seja notado que, se Anselmo pensou em "proposições" não "pensamentos", mas "proposições" - como um tipo de "linguagem mental", tal como pensadores medievais o fariam, ele não teria então necessidade de supor, como parece supor na explanação da verdade de orações enunciativas, já oferecida, que Deus cria "tipos de enunciados" de linguagem natural. Afinal, assim asseveram os autores, nesse caso os enunciados expressariam uma linguagem mental ou um pensamento - em que a equiparação do "pensamento" com a "linguagem mental" ou a "proposição mental" fica evidenciada -, o qual é o mesmo em todos os seres humanos, porque é uma função dos poderes (cognitivos) concedidos por Deus qua Verdade Suprema. Nesse sentido, Visser e Williams podem

${ }^{65}$ Em uma leitura mais antiga, BOEHNER, Ph. et GILSON, É., op. cit., p. 259, também se referem à verdade do pensamento como a "verdade da proposição interior ou anímica". Também os tradutores e/ou responsáveis pela edição espanhola, cf. Anselmo de Cantuária, De veritate - De la verdad, in: idem, Obras completas de San Anselmo, 1952, p. 499-500, nota 1, não entenderam corretamente esse tipo de verdade, que dizem ser "da opinião ou do juízo interno", "um pouco menos conhecida e muito semelhante à primeira". Lembram que a proposição é "verdadeira" quando afirma a existência de algo que é ou a não existência daquilo que não é; agora, no Capítulo III, entendem que Anselmo afirma que 0 "costume" fez com que se chame de "verdadeiro" um "juízo" só quando afirma o ser ou o não ser, quando uma coisa é ou não é, sendo o "juízo", do contrário, falso. Dizem ainda que, tal como quando da enunciação, a "opinião" tem duas classes de verdades: (i) a natural ou a secundária e (ii) a formal ou a moral e voluntária. Mas, isso, para todos os efeitos e minimamente dito, não consta em absoluto no texto original.

66 VISSER, S. e WILLIAMS, Th., Anselm on Truth, in: DAVIES, B. and LEFTOW, B.(eds.), op. cit., p. 209, assim traduziram 0 trecho, a partir da segunda fala do discípulo: "According to the reasoning we found persuasive in the case of statements, nothing can be more correctly called the truth of a thought than its rectitude. For the power of thinking that something is or is not was given to us in order that we might think that what-is is, and that what-is-not is not. Therefore, if someone thinks that what-is is, he is thinking what he ought to think, so his thought is correct. If, then, a thought is true and correct for no other reason than that we are thinking that what-is is, or that what-is-not is not, its truth is nothing than its rectitude". Tradução: "De acordo com o raciocínio que achamos persuasivo no caso dos enunciados, nada pode ser mais corretamente chamado de a verdade de um pensamento do que a sua retidão. Pois o poder de pensar que alguma coisa ou é ou não é nos foi dado no intuito de que pudéssemos pensar que o que-é é, e que o que-não-é não é. Portanto, se alguém pensa que o que-é é, ele está pensando o que deveria pensar, e assim o seu pensamento é correto. Se, então, um pensamento é verdadeiro e correto por nenhuma outra razão senão que pelo fato de que estamos pensando que o que-é é, ou que o que-não-é não é, a sua verdade não é nenhuma outra coisa que a sua retidão". 
sugerir que a verdade de enunciados poderia ser analisada em termos da verdade do pensamento ou da linguagem mental - em que, no fundo, a função desses dois tipos de verdade, de enunciados falados da linguagem natural e da linguagem mental, torna-se muito parecida em teleologia e aplicação, apenas em níveis diferentes, a saber, o falado e o mental. Porém, os autores reconhecem que em geral, e "infelizmente", não se pode observar que Anselmo pense dessa maneira acerca de proposições, a saber, como proposições mentais ${ }^{67}$. Creio, no entanto, que toda essa abordagem é recheada de equívocos ou, ao menos, configura provável precipitação.

Primeiramente, é questionável que provenha de Anselmo o título do Capítulo III do De veritate - se provém, nesse caso tanto não se pode esquecer que só então no título do capítulo o vocábulo "opinio" é utilizado em De veritate (e é inexpressivo alhures na obra anselmiana) como que, sendo todo o discurso sobre esse item "portador" de verdade explanado pela verdade da "cogitatio" (que, como é sabido, também alhures na obra anselmiana é um conceito-chave), "opinio" teria de ser explicado pelo vocábulo "cogitatio", e não o contrário. Afinal, “opinio" e "cogitatio” não são lexicalmente sinônimos ${ }^{68}$, não são em si filosoficamente equiparáveis (pois uma opinião denota, como uma conjetura, uma atitude cognitiva com respeito a um conteúdo proposicional do qual não se tem certeza nem evidência ${ }^{69}$ e um pensamento denota tanto uma atitude cognitiva em sentido lato quanto, mais simplesmente, um dado conteúdo inteligível na mente, simples ou complexo, que dá ele mesmo forma à mente quanto é termo de suas operações ${ }^{70}$ ) e tampouco parecem ser teoricamente equiparáveis na intenção de Anselmo, uma vez que ele de resto não faz qualquer uso intercambiável de tais expressões. Como tal, "verdade da opinião", diferentemente de "verdade do pensamento", está condenada desde o início a ser textualmente uma abordagem inexpressiva na obra de Anselmo: em resumo, Anselmo só se pronuncia sobre a cogitationis veritas. Em segundo

${ }^{67}$ Cf. VISSER, S. e WILLIAMS, Th., op. cit., p. 220-221.

${ }_{68}$ Creio que isso fica definitivamente estabelecido para quem confere Egidio Forcellini, Lexikon Totius Latinitatis, Tomus I (cogitatio), p. 671, e Tomus III (opinio), p. 497-498. Há, naturalmente, como encontrar "cruzamentos" ou " familiaridades" entre as expressões; cf. ENDERS, M. Wahrheit und Notwendigkeit, p. 143-146.

${ }^{69}$ Nesse sentido, seria mesmo difícil compreender que tal atitude cognitiva pudesser ser pretendida, por sua própria natureza, ser portadora de verdade.

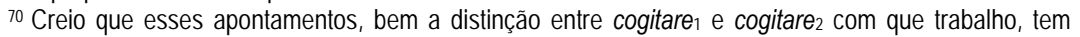
plena ratificação na exposição refinada de COSTA MACEDO, J. M. Anselmo e a astúcia da razão, p. 5862, que pressupõe abertamente o sentido de "cogitare" no Monologion. 
lugar, é pura e simplesmente questionável que se possa ousar equiparar "cogitatio", em De veritate III e demais capítulos em que aparece, com "propositio", "oratio mentalis" ou "enuntiatio mentalis", uma vez que há em Anselmo contextos em que se poderia ganhar acerca de "cogitatio" um sentido bem determinado, por exemplo, justamente os Capítulos II e IV do Proslogion $^{71}$. Mais simplesmente, se é da verdade da cogitatio que Anselmo fala e se é cogitatio o conceito que lhe é caro, é para esse conceito, então, que faz sentido procurar em sua obra parâmetros de entendimento bem delineados. Os contextos em que Anselmo desenvolve reflexões sobre ou baseadas em cogitatio e cogitare levam ao entendimento de que cogitationes são ou podem significativamente ser tomados como sendo conteúdos mentais simples ou complexos, conteúdos, pois, que dão forma à mente ${ }^{72}$, e/ou as atitudes cognitivas que a mente pode adotar com respeito aos conteúdos mentais. Em minha opinião, sob esse aspecto Proslogion, Liber apologeticus e De veritate podem servir-se mutuamente para melhor serem compreendidos, ou seja, para que melhor se compreenda tanto (i) o argumento de Anselmo quanto (ii) a verdade do pensamento.

Reconheço que Anselmo não faz uso da expressão “cogitatio” em Proslogion II-IV; ali, porém, faz uso à exaustão de "aliquid cogitare" e "aliquid cogitari", isto é, recorre à idéia de "pensar algo" ou de "algo ser pensado" para exprimir, famosamente o sentido (sinonímico) de "ter no coração" (in corde habere) e daí, com especificação, "ter no intelecto" (in intellectu esse, in intellectu habere) ou "inteligir" (intelligere) e "inteligir ser" (intelligere esse). Em todos esses casos, a meta é "pensar" a idéia do máximo pensável, ou seja, a idéia de Anselmo - o aliquid quo... - é o conteúdo que é pensado e precisa ser pensado de forma especial para que o argumento seja efetivo. Cogitare-cogitatio expressaria, pois, atos intelectuais que são tipos de pensamento e teria de supor ao mesmo tempo conteúdos pensados de que se tem os tipos de pensamento: expressaria, portanto, pensamentos de pensamentos ${ }^{73}$, sem que Anselmo

\footnotetext{
${ }^{71}$ Sobre "cogitare" no Monologion, cf. a nota anterior; cf. também id. ibid., p. 93ss.

$72 \mathrm{Cf}$. acima notas 7, 8, 9 e 10.

${ }^{73}$ Aqui reside o meu desconforto com a tradução adotada por ENDERS, M., in: Anselm von Canterbury, Über die Wahrheit, 2001, Capítulo 3, p. 19-21: "Über die Wahrheit des Gedankens". Ao optar por "der Gedanke" para a tradução de "cogitatio", ENDERS, M. decidiu-se por um sentido rigorosamente proposicional-mental na interpretação do vocábulo, direcionando assim todo o restante da exegese: De veritate III nivela-se a De veritate II, apenas transferindo ao mental a reflexão sobre enunciados ou proposições como portadoras de verdade. No entanto, sem fazer uso da própria obra de Anselmo, em
} 
sistematicamente tenha se esforçado em discernir os dois aspectos analisados, mas sem que pudesse na prática, em Proslogion II e IV bem como no Liber apologeticus, deixar de fazê-lo. Reitero que Anselmo acentua esses aspectos de cogitare nos momentos reflexivos decisivos do Proslogion, nos Capítulos II e IV, de duas formas: (i) uma coisa é ter ou estar a coisa no entendimento e (ii) outra coisa é inteligir que a coisa é (Proslogion II); ou ainda "dizer no coração" ("pensar") é por um lado (i') ter na mente ou pensar uma palavra significativa ou uma palavra que significa uma coisa, e por outro lado "dizer no coração" ("pensar") é (ii') inteligir aquilo mesmo que a coisa é (Proslogion IV), em que, para os casos (i)-(i') cogitare é pensar uma coisa e para os casos (ii)-(ii') cogitare é inteligir que uma coisa é. $\mathrm{O}$ exemplo direto com o qual Anselmo ilustra o que chamei de cogitare $_{1}$ e cogitare $_{2}$ é o do pintor e da pintura (cf. acima), e ele tanto exige que os dois aspectos de cogitare-cogitatio sejam tratados em conjunto quando impõe o traço da intencionalidade ao cogitare $_{2}$ : pensar-aideia-de-alguma-coisa-não-existente é (pensar um pensamento e) um cogitare $_{1}$; pensar-a-ideia-de-alguma-coisa-existente é (pensar um pensamento e) um cogitare $_{2}$. Os exemplos diretos com os quais Anselmo ilustra a distinção que foi por mim assim denominada são é claro, e fundamentalmente, a "ideia de Anselmo" (aliquid quo...) e os conteúdos complexos daí derivados, isto é, "Deus não existe" e "Deus existe [verdadeiramente]".

seus casos mais acentuados de reflexão sobre cogitare-cogitatio, ENDERS, M. pode ter optado por um impedimento arbtrário ao que bem cabe dentro das intenções de Anselmo. Isso pode ser conferido ao ler-se as notas 31, 32 e 33, in: ENDERS, M., Anmerkungen des Herausgebers, in. Anselm von Canterbury, Über die Wahrheit, p. 87. Ali, o tradutor explicita a opção por "der Gedanke", em declarada discordância com SCHMITT, (que traduzira "cogitatio" por "das Denken"), em razão do fato de que "portador da verdade" não é a "atividade de pensar", mas só o "juízo pensado", em que "juízo pensado" tem paralelo com "juízo linguisticamente expressado". Como citado pelo próprio autor-tradutor, essa mesma posição é detalhada in: ENDERS, M., Wahrheit und Notwendigkeit, p. 171-175, e ratificada in: G. Kapriev, op. cit., p. 123. Em realidade, na nota 33, ENDERS, M. justifica tal acepção de "cogitatio" a partir da idéia de que a determinação de "cogitare" em Monologion, Proslogion e controvérsia com Gaunilo revela que "cogitare" é uma "apreensão espiritual de conteúdos proposicionais logicamente possíveis", ou seja, de cogitationes. Dois são os problemas aqui: (i) primeiramente, Anselmo não faz uso de "cogitare" somente para apreender espiritualmente "conteúdos proposicionais", mas com toda clareza, para apreender "ideias" ou "conteúdos", sejam eles simples ou complexos, tais como o complexo "aliquid quo..."; em segundo lugar, como mostrarei logo abaixo, Anselmo não só não explana rigorosamente a verdade da cogitatio, em De veritate III, tal como se cogitatio fosse unicamente um conteúdo proposicional como, em realidade, explana discursivamente cogitatio como (no mínimo também) uma atividade espiritual. Cf. ainda ENDERS, M., Einleitung, in: Anselm von Canterbury, Über die Wahrheit, p. xxxv-xxxvii. 
Ora, cabe perceber que também em De veritate III, apesar de falar, sim, de "pensamento verdadeiro" (cogitatio vera), Anselmo exprime o que é o pensamento (verdadeiro) em termos de atos intelectuais ou intelecções, ou seja, também descreve o pensamento ali em termos do ato de pensar ou considerar, pela mente, com conteúdos pensados ou pensamentos, o ser ou o existir de algo, o não ser ou o não existir de algo. Essa acepção consta na seção decisiva do capítulo, a segunda fala do discípulo. Essa segunda fala e definição trabalha sutilmente em cima da primeira definição do pensamento verdadeiro - e, por contraste, do pensamento falso -, posta à disposição pelas palavras do mestre:

$\mathrm{D}_{1}$ Um pensamento é verdadeiro quando é [de fato] aquilo que ou bem pela razão ou de algum modo (pela imaginação ou por conjetura) alguém considera que seja.

Essa definição é inquietantemente vaga. Ela ao menos dá a entender, como é possível ler pela segunda definição, exigida pelo mestre, concedida pelo discípulo e finalmente ratificada pelo mestre, que é preciso determinar em que aspectos pensamentos podem ser ou apresentar-se na mente, para que um ser humano, pelo pensar, possa considerá-los ou reconhecer neles esses mesmos aspectos. O que quero dizer é que, nesses termos, um pensamento é verdadeiro se, sendo o que é ou tendo os aspectos que tem, um ser humano reconhecer o que ele é ou considerar os aspectos que ele tem: tal como ele é, ele vem a ser pensado por um ser humano cogitante. Não parece, então, que a cogitatio vera já pode ser tomada aqui como um pensar verdadeiro, em que pensa-se que o conteúdo na mente (o pensamento) é tal e tal, e o conteúdo na mente (o pensamento) é de fato tal e tal? De todo modo, como foi o caso com os enunciados falados, em De veritate II, o que decidirá a verdade do pensamento - que tomo como equivalendo a "o-pensar-que-um-pensamento-é-tal-e-tal" - é, como estipula a segunda fala do discípulo, o que puder ser explanado como a sua "retidão" (rectitudo), a qual se impõe ou se inscreve nele, determinando quando é e explicando por que é "verdadeiro", quando é verdadeiro. Eis, portanto, a segunda e agora mais reveladora definição da cogitatio vera:

$\mathrm{D}_{2}$ Um pensamento é verdadeiro quando alguém pensa (ou considera) ser o que é, ou então quando alguém pensa (ou considera) não ser o que não é - novamente, a falsidade é definida por contraste. 
Mas, por certo algo está faltando para que o tema da verdade do pensamento ganhe uma exposição mais clara e, assim eu creio, mais relevante. Nesse sentido, entendo que algumas paráfrases e expansões das fórmulas dadas precisam ser propostas. Afinal, a definição, incluindo a sugestão de haver um poder que o ser humano possui de pensar que algo é ou que algo não é, não pode literalmente rezar que (primeira paráfrase) "um pensamento é verdadeiro quando alguém considera ser ele o que ele é", mas, em um sentido de aplicação (segunda paráfrase), "um pensamento é verdadeiro quando alguém considera, com e por meio dele, ser ou existir o que é ou existe", ou seja (terceira paráfrase), "um pensamento é verdadeiro quando alguém considera, com e por meio dele, ser ou existir aquilo[74] de que ele é um pensamento". Tal sentido aplicado da verdade do pensamento pressupõe, sem dúvida, uma função ou uma norma inscrita nos pensamentos qua conteúdos da e na mente ${ }^{75}$, em que, tal qual o seu aspecto de ser um pensamento do que é ou do que existe, "deve-se" ou "é reto" que alguém considere ou pense que a coisa ou o aliquid é ou existe, ou em que, tal qual o seu aspecto de ser um pensamento do que não é ou do que não existe, "deve-se" ou "é reto" que alguém considere ou pense que a coisa ou o aliquid não é. Cabe reescrever a segunda definição:

$\mathrm{D}_{2}$, Um pensamento é verdadeiro quando alguém pensa (ou considera), com e por meio dele, ser ou existir aquilo de que ele é um pensamento, ou seja, ser ele um pensamento do que é ou existe, quando ele assim o é, ou então quando alguém considera, com e por meio dele, não ser ou não existir aquilo de que ele é um pensamento, ou seja, ser ele um pensamento do que não é ou não existe, quando ele assim o é - novamente, a falsidade é definida por contraste.

Dessa maneira, porém, pareceria que cogitatio voltou a ser só o conteúdo mental; um conteúdo ou proposição mental, por sua vez, nem sequer precisa necessariamente ser pensado atualmente por alguém para que seja verdadeiro. Mais ainda, e talvez mais importante, o que foi dado como portador de verdade ou um veritativo, determinado em função ou teleologia,

\footnotetext{
${ }^{74}$ Conforme 0 texto latino, cf. a nota 62 acima, o discípulo, na segunda fala, invoca a capacidade de pensar que "algo" (aliquid) é ou não é. É isso que é enfatizado também na breve observação sobre De veritate III feito por SCHMITT, , Einführung, in: Anselm von Canterbury, op. cit., p. 12.

75 Inscreve-se nos pensamentos que funcionam por poderem ter ou não intencionalidade e por poderem ser aplicados, em atos intelectuais, correspondentemente ao terem ou não intencionalidade.
} 
na segunda fala do discípulo foi o poder pensar, que quando exercido cai, como um veritativo, sob a dita teleologia de como deve ser a operação. Por isso mesmo, um retoque à definição acima se faz requerido, e pode ser feito facilmente:

$\mathrm{D}_{2}$, Um pensamento é verdadeiro quando alguém pensa (ou considera), com e por meio de um pensamento (ou um conteúdo mental), ser ou existir aquilo de que esse último é um pensamento, ou seja, ser ele um pensamento do que é ou existe, quando ele assim o é, ou então quando alguém considera, com e por meio de um pensamento (ou um conteúdo mental), não ser ou não existir aquilo de que esse último é um pensamento, ou seja, ser ele um pensamento do que não é ou não existe, quando ele assim o é - novamente, a falsidade é definida por contraste.

A palavra "pensamento" que consta no início da definição é o poder pensar, o ter atos de pensamentos, o operar com pensamentos. $\mathrm{O}$ pensamento-atividade, pois, só é verdadeiro e reto porque considera-se existir o que existe, ou não existir o que não existe. Claro está que a ênfase reside no vínculo com a existência ou a não existência - a existência de algo ou a não-existência de algo - do que é pensado com o pensamentoatividade: deve-se considerar existir o que existe, quando no exerício de pensar o que existe; deve-se considerar não existir o que não existe, quando no exercício de pensar o que não existe. Antes de refletir sobre o vínculo estreito entre essas considerações acerca da verdade do pensamento e os termos da doutrina do pensamento ou do cogitare que Anselmo esboça no Proslogion, dois últimos pontos ainda merecem ainda atenção.

Primeiramente, é relevante anotar uma passagem, em De veritate $\mathrm{X}$, em que Anselmo, afirmando a dependência de todas as formas de verdade com respeito à Verdade Suprema, pondera sobre a relação de dependência (secundária) que algumas formas de verdade têm com respeito a outras e adverte, portanto, que algumas verdades ou retidões são apenas "efeitos", outras verdades ou retidões, porém, são tanto "causa" quanto "efeito", e uma só, a Verdade Suprema que é Deus, é somente "causa" e jamais "efeito". Em conformidade com isso, a verdade que é "na existência das coisas", isto é, a verdade de essência ou que diz que a retidão de ser tal é concordar com o seu ser assim constituída em Deus, é - em uma posição 
destacada, pois ${ }^{76}$ - tanto efeito da Verdade Suprema quanto causa (sic!) da verdade do pensamento (cogitatio) e da verdade que é na proposição (propositio) - ao passo que essas duas últimas, como verdades ou retidões, são apenas efeitos e não causam, pois, nenhuma verdade (nullius sunt causa veritatis $)^{77}$. Consequência importante dessa passagem, em um primeiro olhar, é que definitivamente Anselmo não concebe a verdade do pensamento como tendo qualquer vínculo causal com a da enunciação falada, o que compromete a tendência de leitura de que se teria, em uma e em outra, os níveis do veritativo que seriam designados como "juízo mental" e "juízo falado". Ademais, isso poderia ao menos inclinar alguém à convicção, caso fosse refletido hipoteticamente sobre uma teoria da origem ou da causa de pensamentos - qua conteúdos mentais -, que esses (materialmente) são o que são porque ou bem dependem do que existe ou não dependem do que existe, a saber, que as coisas existentes e com verdade essencial porque em sua essência constituídas por Deus causam ou originam pensamentos e pensamentos (acidentalmente) verdadeiros ${ }^{78}$. Esses, pensamentos então, quando são pensados ou considerados ser da coisaessência que é, e eles assim o são, compõem justamente a "verdade do pensamento" em Anselmo: o operar da mente com pensamentos como pensamentos do que existe, quando eles assim o são, ou o operar da mente com pensamentos do que não-existe, quando eles assim o são - quando pensamentos não são causados por coisas existentes e em sua essência constituídas por Deus, eles só podem ser verdadeiros se, seja o que forem, considera-se que eles não são de uma coisa essencial que é, tal como eles, efetivamente, não o são.

Em segundo lugar, a abordagem que ofereço não tende a aproximar o tema de De veritate III (cogitatio) ao tema de De veritate II (enuntiatio); em realidade, a única semelhança que Anselmo insiste em dizer haver entre ambos é que a verdade em um e em outro caso é a "retidão" (rectitudo). A

\footnotetext{
${ }^{76} \mathrm{Cf}$. acima nota 48.

${ }^{77} \mathrm{Cf}$. De veritate X (ed. BAC: 520): "D. - Video et animadverto in aliis quasdam esse tantum effecta, quasdam vero esse causas et effecta. Ut cum veritas, quae est in rerum exsistentia, sit effectum summae veritatis, ipsa quoque causa est veritatis, quae cogitationis est, et eius, quae est in propositione; et istae duae veritates nullius sunt causa veritatis. M. - Bene consideras".

78 No mesmo sentido discorrido acima, na segunda parte do estudo, sobre como os estados de coisas causam acidentalmente a verdade de enunciados falados; essências e estados de coisas não causam, porém, a retidão ou o dever-ser inscrito seja nos enunciados falados seja no operar com pensamentos (0 modo fundamental, portanto, como entendo a "cogitatio" da qual Anselmo trata em De veritate III).
} 
abordagem aqui desenvolvida aproxima o tema de De veritate III ao de De veritate IV (voluntas). A verdade da vontade consiste em fazer ou querer com a vontade o que é devido, cumprindo o motivo de ter-se recebido esse poder: verdade ou retidão na vontade é querer o que se deve querer ${ }^{79}$, operar, portanto, de forma devida, quando se opera, ou seja, querer o bem em si e por si mesmo quando se dá poder querê-lo. Esses aspectos são ratificado magnificamente em De veritate $\mathrm{V}$, em que, sobre a verdade da ação natural-necessária (como o arder do fogo) ${ }^{80}$ ou não-natural-livre (o agir ou o querer do ser humano) ${ }^{81}$, ser verdadeiro está no plano de veritatem facere ou rectitudinem facere, de um poder de agir, seja natural ou nãonatural, que cumpre o devido e é reto ao operar a teleologia que nele se inscreveu ${ }^{82}$.

Essas convicções parecem ser ratificadas pelo que se pode depreender do Capítulo IX do De veritate, que reza "Que toda ação significa o verdadeiro e o falso". O capítulo começa ponderando que o

${ }^{79}$ Cf. Anselmus, De veritate IV (ed. SCHMITT, 1966, p. 46): "M. - Dic ergo quod ibi intelligas veritatem. D. Non nisi rectitudinem. Nam si, quamdiu voluit quod debuit, ad quod scilicet voluntatem acceperat, in rectitudine et in veritate fuit, et cum voluit quod non debuit, rectitudinem et veritatem deseruit: non aliud ibi potest intelligi veritas quam rectitudo, quoniam sive veritas sive rectitudo non aliud in eius voluntate fuit quam velle quod debuit".

${ }^{80} \mathrm{Cf}$. Anselmus, De veritate V (ed. SCHMITT, 1966, p. 48): "D. - Si ignis ab eo, a quo habet esse, accepit calefacere: cum calefacit, facit quod debet. Igitur non video, quae inconvenientia sit ignem facere veritatem et rectitudinem, cum faciat quod debet".

${ }^{81}$ Cf. Anselmus, De veritate V (ed. SCHMITT, 1966, p. .50): "M. - Mihi quodque non aliter videtur. Unde animadverti potest rectitudinem seu veritatem actionis aliam esse necessariam, aliam non necessariam. Ex necessitate namque ignis facit rectitudinem et veritatem, cum calefacit; et non ex necessitate facit homo rectitudinem et veritatem, cum bene facit. (...). M. - (...). Sed quoniam de veritate investigando illam loquimur, et Dominus de illa veritate, quae in voluntate est, specialiter dicere videtur, cum dicit de diabolo quia in veritate non stetit: ideo separatim, quid in voluntate veritas esset, considerare volui".

82 Cf. Anselmus, De veritate V (ed. SCHMITT, 1966, p. 48): "Quapropter si veritatem facere et bene facere idem sunt in oppositione, non sunt diversa in significatione. Sed sententia est omnium quia, qui facit quod debet, bene facit et rectitudinem facit. Unde sequitur quia rectitudinem facere est facere veritatem. Constat namque facere veritatem esse bene facere, et bene facere esse rectitudinem facere. Quare nihil apertius quam veritatem actionis esse rectitudinem". Cf. também id. ibid. V (ed. SCHMITT, 1966, p. 50-52), em que na última fala do discípulo dentro deste capítulo há uma reconsideração da "verdade da oração", exposta no Capítulo II, como uma forma de verdade de ação natural (!): "M. - Cum ergo constet actionis veritatem aliam esse naturalem, aliam non naturalem: sub naturali ponenda est illa veritas orationis, quam supra vidimus ab illa non posse separari. Sicut enim ignis, cum calefacit, veritatem facit, quia ab eo accepit, a quo habet esse: ita et haec oratio, scilicet 'dies est', veritatem facit, cum significat diem esse, sive sit dies sive non sit; quoniam hoc naturaliter accepit facere". A ideia parece ser a de que da verdade da significação não se pode deixar de dizer que ela em parte é ou pressupõe a verdade da ação natural do falar mesmo um enunciado como 'É dia' (um enunciado-tipo de uma linguagem) sob a "normatividade" inerente de que fala-se um certo enunciado para significar o que é ou o que não é o caso. 
tratamento da verdade admite uma crescente complexificação, que, retomando a lista já extensa de portadores de verdade, pode de novo trazer detalhamentos para cada item - inicialmente, novamente para a "verdade da significação" (veritas significationis) ou dos enunciados. Em resumo, Anselmo quer dizer que há erro e verdade em toda e qualquer forma de ação no simples fato de agir-se: quando alguém fala, ou bem está fazendo ao falar o que deve fazer (dizer a verdade) ou o que não deve fazer (mentir) ${ }^{83}$; quando fala e age com respeito ao que diz, ou bem está fazendo o que deve fazer (comportar-se coerentemente, ao falar que tais ervas são venenosas e não comê-las) ou o que não deve fazer (comportar-se incoerentemente, ao falar que tais ervas são boas, mas comer as que dissera ser venenosas), inscrevendo-se, portanto, no agir-comportar-se um dever ser que diz qual é a sua condição de verdade ${ }^{84}$. Ao final do capítulo, no entanto, Anselmo expande a análise da verdade do agir em geral, oferecendo em conjunto uma reflexão acerca do pensar e do querer alguma coisa:

M. - (...). Semelhantemente, quando alguém pensa ou quer alguma coisa, se ignorásses se porventura ele deveria querer ou pensar aquilo: se visses a vontade e o pensamento dele, significaria para ti, pela própria operação, que isto ele deveria pensar e querer. Pois, se dessa maneira devesse [pensar e querer], [então] dirá o verdadeiro. Do contrário, porém, mentirá. Na existência das coisas, com efeito, está semelhantemente a verdadeira ou a falsa significação, visto que, pelo fato mesmo de que é, diz que ela deve ser ${ }^{85}$.

\footnotetext{
${ }^{83}$ Cf. Anselmus, De veritate IX (ed. SCHMITT, 1966, p. 66-68): "M. - Videamus ergo, quam lata sit veritas significationis. Namque non solum in iis, quae signa solemus dicere, sed et in aliis omnibus, quae diximus, est significatio vera vel falsa. Quoniam namque non est ab aliquo faciendum, nisi quod quis debet facere, eo ipso quod aliquis aliquid facit, dicit et significat hoc se debere facere. Quod si debet facere quod facit, verum dicit. Si autem non debet, mentitur".

${ }^{84}$ Cf. Anselmus, De veritate IX (ed. SCHMITT, 1966, p. 68): "M. - Si esses in loco, ibi scires esse salubres herbas et mortiferas, sed nescires eas discernere; et esset ibi aliquis, de quo non dubitares quia illas discernere sciret, tibique interroganti, quae salubres essent et quae mortiferae, alias verbo diceret salubres esse et alias comederet: cui magis crederes, verbo an actioni eius? D. - Non tantum crederem verbo quantum operi".

${ }^{85}$ Cf. Anselmus, De veritate IX (ed. SCHMITT, 1966, p. 68): "M. - (...). Similiter cum cogitat aliquis aut vult aliquid, si nescires, an deberet id velle sive cogitare: si voluntatem eius et cogitationem videres, significaret tibi ipso opere quia hoc deberet cogitare et velle. Quod si ita deberet, verum diceret. Sin autem, mentiretur. In rerum quoquer existentia est similiter vera vel falsa significatio, quoniam eo ipso quia est, dicit se debere esse".
} 
Pode-se depreender que Anselmo fala de "performances", em especial das performances de enunciar e de comportar-se com o uso de enunciados respectivos e relevantes ao contexto de ação - embora não pareça tematizar "atos de fala". As performances podem ser mais ou menos complexas. E parece haver um sentido em que performances de enunciar, mesmo se não acompanhadas de comportamento, sempre envolvem outras operações, em particular pensar e/ou querer; em especial, há um sentido em que pensar e querer sempre são operações simples ou "comportamentos" internos não-ilusórios, eles são o que são: translúcidas a uma mente que pudesse "vê-las", essas operações enquanto operam, dado o dever que nelas se inscreve como tipos de operações, revelar-se-iam como espécimes verdadeiros ou falsos. Não sendo, porém, translúcido o enunciar composto por pensar e querer (diferentemente do enunciar composto por comportarse, diga-se, com gestos e ações), porque justamente o pensar e o querer não são translúcidos a um que ouve um enunciado falado como "Sereias existem", tem-se como resultado que performances que são compostos de enunciar-pensar-querer podem ser falsas - porque indevidas - por causa de um querer falso (porque indevido) e/ou por causa de um pensar falso (porque indevido). É presumível que um pensar falso seja condição suficiente para um enunciar falso como performance. De todo modo, a passagem acentua decisivamente que pensar e querer são tratados por Anselmo como operações, como atos de poderes, e assim "têm" a sua verdade. De forma interessante, mas distinta do relato em De veritate II, pode-se analisar também o "emitir enunciados" como uma operação composta $^{86}$. Trata de mais um item veritativo.

\section{A verdade do pensamento e a existência do aliquid quo nihil maius cogitari potest. observações finais}

Há por certo estratégias interpretativas diversas para dar seguimento à sugestão de que é somente atentando para um nexo profundo entre as verdades específicas e a Verdade Suprema única, Deus mesmo, que se pode compreender o(s) argumento(s) anselmiano(s) a favor da existência de

\footnotetext{
${ }^{86}$ VISSER, S. e WILLIAMS, Th., Anselm on Truth, in: DAVIES, B.and LEFTOW, B.(eds.), op. cit., p. 208, chegam a sugerir que seria possível construir, no caso dos enunciados falados, uma teleologia respectiva ao poder, dado por Deus, "de usar a linguagem, em vez de constrú́-la nos próprios tipos de enunciados", mas notam que essa não é a intenção de Anselmo (ao menos em De veritate II).
} 
Deus $^{87}$. A percepção inicialmente simples e a ser mantida, assim entendo, é a de que os usos de "vere" e "veritas" no Proslogion insinuam que "verdade" como modo e substantivo refere-se ao ser real ou existir e à existência e à natureza de uma entidade: a primeira intenção de prova é (i) mostrar que "Deus é verdadeiramente" (Deus vere est) ${ }^{88}$, em que vere esse e existere [ou: esse] in re podem perfeitamente ser tomados como sinônimos verbais $^{89}$. Além disso, (ii) identifica-se na estrutura do Proslogion a intenção de "entender a tua verdade [a saber, a de Deus] de alguma maneira" (aliquatenus intelligere veritatem tuam), em que é bastante simples supor que a "verdade" a ser sabida resume os passos do argumento geral, a saber, mostrar (a) que Deus existe na realidade e (b) que Deus é o sumo bem ${ }^{90}$. Por outro lado, embora envolva saber da existência e mesmo da natureza de algo, a "verdade" no De veritate, associada a diversos portadores, mas unificada na sua dependência normativa e original, em termos de constituição e finalidade, por uma só Verdade Suprema, é pois precipuamente a realização particular de finalidade por parte dos veritativos, a saber, os enunciados falados, os pensamentos, as volições, etc., quando em uso ou em operação.

Nesses termos, entendo que a hipótese de trabalho aqui desenvolvida tem prima facie sucesso, a saber, que a doutrina do pensar em Proslogion II-IV e a do pensamento em De veritate se complementam ou, antes, mostram mútua compatibilidade produtiva. Um vínculo teoricamente produtivo entre a prova do Proslogion e a teoria anselmiana da verdade pode ser estabelecido pelo fato de aquele argumento pressupor certa teoria do cogitare e ainda uma posse bem definida, e cada vez mais determinada,

\footnotetext{
87 Cf. BOEHNER, Ph. et GILSON, É., op. cit., p. 260. O próprio Anselmo, segundo os autores, e particularmente com respeito ao Monologion, "não deixou de insinuá-lo"; cf. Anselmus, De veritate X (ed. SCHMITT, 1966, p. 70): "M. - (...). Unde iam intelligere potes, quomodo summam veritatem in meo Monologio probavi non habere principium vel finem per veritatem orationis". Assim, cf. id. ibid., p. 261, "0 nervo oculto das mesmas [das provas anselmianas da existência de Deus] é o conceito anselmiano de verdade". Afinal, seria justamente nessa doutrina de Anselmo que confluem quatro linhas de pensamento: (i) a anterioridade das essências em relação aos indivíduos, (ii) a realidade dos universais, (iii) a independência da verdade em relação às coisas das quais é predicada e (iv) a existência fundante da verdade em Deus.

${ }^{88} \mathrm{Cf}$. acima nota 2.

${ }^{89}$ Cf., por exemplo, as últimas linhas de Anselmus, Proslogion II (ed. SCHMITT, 1961, p. 84): "Existit ergo procul dubio aliquid quo maius cogitari non valet, et in intellectu et in re". Ora, se o tema do capítulo é "quod vere sit Deus", o uso do verbo "existere" na linha conclusiva é manifestamente no sentido de "existere in re" ou "existere in realitate".

$90 \mathrm{Cf}$. acima nota 2.
} 
da "idéia de Anselmo", o aliquid quo nihil maius cogitari potest, rigorosamente classificada quando dando forma (em ato) à mente como um tipo de pensamento, e não outro. Esse tipo de pensamento (o pensar a ideia de intencionalidade necessária e única), bem como o que logicamente se deriva desse tipo de pensamento (o pensar a proposição de existência que diz existir o sujeito ou o designado pela ideia), pode ser chamado de "pensamento verdadeiro" - em que novamente faço uso precípuo de pensamento como ato de pensar, mas que envolve pensamento ou conteúdo mental como aquilo com o que se pensa (ou não se pensa) aquilo que existe. Sobre o conteúdo mental, entendo ser inegável que o Proslogion trabalha tanto com algo como uma "ideia" quanto com algo (derivável do conteúdo de uma "ideia") como uma proposição - isto é, uma proposição de existência.

Dito isso, relembre-se que Proslogion II e IV autoriza a falar de cogitare $_{1}$ e cogitare 2 , em que o primeiro não é intencional, e o segundo o é. Pode a teoria da verdade do pensamento no De veritate ser comparada a essas noções? Creio que $\operatorname{sim}^{91}$. Entendo que a noção de pensamento verdadeiro, quando aguém pensa, com e por meio de um pensamento, ser ou existir aquilo de que esse último é um pensamento, ou seja, ser ele um pensamento do que é ou existe, quando ele assim o é, compara-se ao cogitare $_{2}$; entendo que a noção de pensamento verdadeiro, quando alguém pensa, com e por meio de um pensamento, não ser ou não existir aquilo de que esse último é um pensamento, ou seja, ser ele um pensamento do que não é ou não existe, quando ele assim o é, compara-se ao cogitare ${ }_{1}$. Assim, pois, o pensar intencional é verdadeiro se, com e por meio de um pensamento ou conteúdo mental (de fato) intencional, considera-se ser esse um pensamento daquilo que existe (ou considera-se existir aquilo de que ele é um pensamento). A falsidade é definida por contraste: o pensar intencional é falso se, com e por meio de um pensamento ou conteúdo mental (tomado como) intencional, considera-se ser esse um pensamento daquilo que existe (ou considera-se existir aquilo de que ele é um pensamento), caso em que a coisa não existe, e o pensamento não é de fato

\footnotetext{
${ }^{91} \mathrm{Cf}$. também, ainda que com nuances diferentes, POUCHET, R., op. cit., p. 80ss. A interpretação que POUCHET, R. oferece aos termos (aproximados) da distinção que estabeleci é particularmente centrada em uma comparação da teoria da linguagem "mental" significativa em Anselmo e aquela de Agostinho no De magistro. Para uma abordagem mais geral, cf. também SYNAN, E. A. Truth: Augustine and Anselm, in: J. C. Schnaubelt et alii (eds.), Anselm Studies. An Occasional Journal, p. 275-295.
} 
intencional. Essa última pode logicamente ser a situação de todo pensar que não o pensar o aliquid quo nihil maius cogitari potest. Finalmente, o pensar não intencional é verdadeiro se, com e por meio de um pensamento ou conteúdo mental (de fato) não intencional, considera-se ser esse um pensamento daquilo que não existe (ou considera-se não-existir aquilo de que ele é um pensamento). A falsidade é definida por contraste: o pensar não-intencional é falso se, com e por meio de um pensamento ou conteúdo mental (tomado como) não intencional, considera-se ser esse um pensamento daquilo que não existe (ou considera-se não existir aquilo de que ele é um pensamento), caso em que a coisa existe, e o pensamento é de fato intencional. Essa última pode logicamente ser a situação de todo pensar, inclusive a do pensar o aliquid quo nihil maius cogitari potest ${ }^{92}$.

Essa acepção da verdade, se correta, sem dúvida ratifica a convicção de que uma certa acepção do pensamento ou da posse de pensamentos serve como elemento central do unum argumentum, no que tange a existência de Deus. Decisivo é conseguir pensar com uma intencionalidade tal - devido à intencionalidade única e necessária inscrita no ser noético mesmo da "ideia de Anselmo" - que essa mesma intencionalidade não só não pode ser logicamente negada como não pode ser, em algum momento, por insipiente qualquer, epistemicamente (ou antes cognitivamente) senão constatada ${ }^{93}$. Para Anselmo ao menos, ela também não precisa (e talvez não possa) ser logicamente explanada por nenhum processo natural de obtenção ou de criação de ideias da mente; Anselmo em momento algum dá a entender que a intencionalidade ou radical "abertura" ao real daquele "dado noético" tenha ou possa ser explanada por algo como, via um princípio de razão suficiente, a ação da própria essência existente sobre o entendimento, complementando o argumento a posteriori e "por indução", como propôs É. Gilson, independentemente de isso acarretar a tese de algum tipo de inatismo de ideias. Creio que uma prova da existência de Deus nesses termos, a partir da "ideia de Deus", e que historicamente se associa a autores como R. Descartes e Malebranche e, na interpretação de Anselmo

\footnotetext{
92 Nesses termos, divirjo do sentido que, em um breve apontamento, CORBIN, M., Prière et raison de la foi. Introduction à lòuvre de Saint Anselme de Cantorbéry, p. 191, deu ao "pensamento" em De veritate III.

${ }_{93}$ Não cabe aqui investigar por que ela não vem a ser constatada, embora obviamente esse ponto seja extremamente importante para pretensões de sucesso argumentativo; cf. sobre isso a dissertação de RIBEIRO, E. S. O argumento epistemológico de Anselmo, p. 67-70.
} 
mais propriamente, a estudos antigos de Beda Adlhoch, Étienne Gilson et alii, mantém uma coerência com o que Anselmo atingiu, pois parte basicamente do que ele estabeleceu e constrói adiante, ao menos para quem solicitar uma teoria da origem das ideias. Repito, porém, que Anselmo não só não realiza esse passo, o de sugerir ainda uma teoria da origem das ideias na mente para chegar, no termo da prova, à origem formal da realidade objetiva da própria ideia na mente, como parece antes sugerir que uma ideia ou um pensamento que apresenta tal força lógica só pode ter sede imediata na verdade ou ser o primeiro reflexo essencial-real da própria Verdade, que, caso já se apresente na mente, lugar único onde é perceptível, revela, se pensada corretamente ou com "retidão", ipso facto a sua realidade ${ }^{94}$. Ora, o De veritate deve convencer o estudioso de que há também aquela "Verdade" perceptível à mente porque há "verdades" ou "finalidades constitutivas" na existência de todas as coisas, sejam elas da mente ou do mundo exterior, sendo que "a Verdade" sempre se mostra logicamente independente das "verdades" e, tal como certas proposições sempre verdadeiras (a partir de essências sempre verdadeiras porque na "Verdade") revelam, "a Verdade" tem de ser eterna ${ }^{95}$. Na sua ratio, Anselmo satisfaz-se com um fato noético vivenciado pela mente, em que ela simplesmente se deixa prender, de forma irrevogável, pelo pensamento verdadeiro de Deus. Identificando no dado noético uma intencionalidade única, lógica e cognitivamente inescapável, o dialético e o insipiente reeducado podem vir a saber, por dedução, da proposição "Deus existe" como portadora daquela mesma intencionalidade.

${ }^{94}$ Cf. POUCHET, R., op. cit., p. 77ss., Cf. também Anselmus, Liber apologeticus V (ed. SCHMITT, 1961: 150): "Ergo si non similiter potest probari de eo quod "maius omnibus" dicitur, quod de se per seipsum probat "quo maius nequit cogitari": iniuste me reprehendisti dixisse quod non dixi, cum tantum differat ab eo quod dixi".

${ }^{95} \mathrm{Cf}$. Anselmus, De veritate XIII (ed. SCHMITT, 1966, p. 92): "M. - An ergo non vides quia non ideo est rectitudo in significatione, quia tunc incipit esse, cum significatur esse quod est, vel non esse quod non est, sed quia significatio tunc fit secundum rectitudinem, quae semper est; nec ob hoc abest a significatione, quia perit, cum non, sicut debet, aut cum nulla sit significatio, sed quoniam tunc significatio deficit a non deficiente rectitudine? (...). M. - Rectitudo igitur, qua significatio recta dicitur, non habet esse aut aliquem motum per significationem, quomodocumque ipsa moveatur significatio. (...). D. - Omnino video hac ipsa ratione probari, quoquo modo ipsa sint, rectitudinem immutabilem permanere". Cf. também HOPKINS, J., A Companion to the Study of St. Anselm, p. 137. Cf. também notas 56 e 57, acima. 
O sucesso da prova anselmiana sem o passo a posteriori mencionado deveria ser de novo perguntado ao insensato e a pessoas como Gaunilo ${ }^{96}-$ que, suponho, funcionam nessa discussão como aqueles, talvez uma maioria, para quem a proposição "Deus existe" precisa ser provada $a$ posteriori. Contento-me, por ora, em ter proposto um bom vínculo entre a teoria anselmiana da verdade do pensamento e o argumento de Anselmo no Proslogion. O passo que está logo adiante na jornada é o de justamente aprofundar" a noção de que, se toda "verdade" de enunciado e de pensamento depende da "verdade" das essências ${ }^{98}$ (tese de Anselmo em De veritate X), que por sua vez depende da "Verdade Suprema", que por sua vez de nada depende porque, (afinal de contas, caso uma "verdade" seja conhecida", é na "Verdade" que ela é conhecida, porque, mesmo se se nenhuma "verdade" fosse conhecida, é ainda na "Verdade" que isso seria conhecido), será correto dizer que, se há tal obrigação intencional disponibilizada pela análise lógica da "ideia de Anselmo", a inscrição que como norma diz a "verdade" desse pensamento só será explicada pela essência divina ou "Verdade Suprema" que "causa" essa idéia como a primeira ideia na ordem, por assim dizer, "lógica" ou das "razões", havendo ou não qualquer proposta de um passo demonstrativo posterior (e $a$ posteriori). Naquele dado noético, o pensar do sujeito racional e a essência divina de certo modo se encontrarão o menos indiretamente possível como a Verdade-causa com a sua primeiríssima verdade-efeito - ou, portanto, somente no tênue limbo da "ideia", ao passo que na posse de toda e qualquer outra verdade, de todo e qualquer outro tipo, o encontro será cada vez mais indireto e remoto.

\footnotetext{
96 O monge Gaunilo, eu creio, foi o primeiro a solicitar o dito complemento "indutivo" da prova anselmiana; Gaunilo, com alguns apontamentos brilhantes, insinua uma teoria empirista sobre a origem das ideias e justamente por causa disso não compartilha e não consegue conceber ou aceitar estritamente o espírito do argumento de Anselmo. Uma abordagem instigante das diferenças sobre "filosofia da linguagem" entre Anselmo e Gaunilo pode ser encontrada in: H. Kohlenberger, Similitudo und Ratio. Überlegungen zur Methode bei Anselm von Canterbury, p. 151-165.

${ }^{97}$ Concedendo um especial peso ao inquérito da "verdade" e do "pensamento" no Monologion.

$98 \mathrm{Em}$ um aspecto a ser verificado, POUCHET, R., op. cit., p. 78, parece interpôr que a verdade das essências comanda a verdade do pensamento por, antes, comandar a verdade dos "signos".

${ }_{99}$ Encontra-se aqui o cerne da adaptação, por Hegel, da concepção anselmiana de verdade; cf., por exemplo, SHANON, D. E. , Hegel Facing Anselm's God, Evil, and Truth, in: FORTIN, J. R. (ed.), Saint Anselm - His Origins and Influence, p. 178-179 (161-182).
} 


\section{Referências Bibliográficas}

CANTERBURY, A. O.. On Truth. In: CANTERBURY, A. O.. The Major Works. Edited with an Introduction by Brian Davies and G. R. Evans. Oxford - New York: Oxford University Press, 1998, p. 151-174.

. On Truth - De veritate. In: CANTERBURY, A. O.. Truth, Freedom, and Evil - Three Philosophical Dialogues. Edited and translated by Jasper Hopkins and Herbert Richardson. Toronto - New York: The Edwin Mellen Press, Vol. II, 1976, p. 75-102.

CANTERBURY, A. O.. De veritate - Über die Wahrheit. Latenisch-Deutsche Ausgabe von P. Franciscus Salesius Schmitt O.S.B. Stuttgart - Bad Cannstatt: Friedrich Frommann Verlag (Günther Hozboog), 1966.

Proslogion. Latenisch-Deutsche Ausgabe von P. Franciscus Salesius Schmitt

O.S.B. Stuttgart - Bad Cannstatt: Friedrich Frommann Verlag (Günther Holzboog), $1961\left({ }^{3} 1995\right)$.

. Quid ad haec respondeat editor ipsius libelli [Liber apologeticus]. Latenische Ausgabe von P. Franciscus Salesius Schmitt O.S.B. Stuttgart - Bad Cannstatt: Friedrich Frommann Verlag (Günther Holzboog), 1961 ( $\left.{ }^{3} 1995\right)$, p. 144154.

Über die Wahrheit. Latenisch-Deutsch. Übersetzt, mit einer Einleitung und Anmerkungen, herausgegeben von Markus Enders. Hamburg: Felix Meiner Verlag, 2001.

CANTUÁRIA, S. A. de. Proslogion. In: CANTUÁRIA, S. A. de. Obras completas de San Anselmo. Edición bilingüe. Madrid: Biblioteca de Autores Cristianos, Tomo I, 1952, p. 351-405.

. De veritate. In: CANTUÁRIA, S. A. de. Obras completas de San Anselmo. Edición bilingüe. Madrid: Biblioteca de Autores Cristianos, Tomo I, 1952, p. 485541.

\section{Literatura secundária}

BARTH, K.. Fides quaerens intellectum. Anselms Beweis der Existenz Gottes im Zusammenhang seines theologischen Programms. München: Chr. Kaiser Verlag, 1931 (Zürich: Evangelischer Verlag AG Zollikon, 1958).

BOEHNER, P. et GILSON, E.. História da filosofia cristã. Desde as origens até Nicolau de Cusa. Petrópolis: Editora Vozes, ${ }^{5} 1991$. 
COLOMBO, G.. Invito al pensiero di Santo Anselmo. Milano: Gruppo Ugo Mursia Editore, 1990.

CORBIN, M.. Prière et raison de la foi. Introduction à lòuvre de Saint Anselme de Cantorbéry. Paris: Les Éditions du Cerf, 1992.

COSTA MACEDO, J. M.. Anselmo e a astúcia da razão. Porto Alegre: EST Edições, 2009.

DAVIES, B.. Anselm and the Ontological Argument. In: DAVIES, Brian and LEFTOW, Brian (eds.). The Cambridge Companion to Anselm. Cambridge: Cambridge University Press, 2004, p. 157-178.

DAVIES, B. and EVANS, G. R. Introduction. In: CANTERBURY, A. O.. The Major Works. Edited with an Introduction by Brian Davies and G. R. Evans. Oxford - New York: Oxford University Press, 1998, p. vii-xxiii.

ENDERS, M.. Anmerkungen des Herausgebers. In: CANTERBURY, A. O.. Über die Wahrheit. Latenisch-Deutsch. Hamburg: Felix Meiner Verlag, 2001, p. 79-105.

. Einleitung. In: CANTERBURY, A. O.. Über die Wahrheit. LatenischDeutsch. Hamburg: Felix Meiner Verlag, 2001, p. xi-cxv.

. Wahrheit und Notwendigkeit. Die Theorie der Wahrheit bei Anselm von Canterbury. Leiden: Brill, 1999.

EVANS, G. R. Anselm's Life, Works, and Immediate Influence. In: DAVIES, B. and LEFTOW, B. (eds.). The Cambridge Companion to Anselm. Cambridge: Cambridge University Press, 2004, p. 5-31.

FLASCH, K.. Zum Begriff der Wahrheit bei Anselm von Canterbury. In: Philosophisches Jahrbuch 72 (1965), p. 322-352.

FORCELLINI, E.. Lexikon Totius Latinitatis. Patavii: Gregoriana, 1965, Tom. I-VI. GILSON, É.. La philosophie au Moyen Age. Des origines patristiques a la fin du $X I V^{e}$ siècle. Deuxième édition revue et augmentée. Paris: Payot, 1947.

Sens et nature de l'argument de S. Anselme. In: Archives de l'histoire doctrinale et littéraire du moyen age 9 (1934), p. 5-51.

The Spirit of Mediaeval Philosophy. Gifford Lectures 1931-1932. Translated

by A. H. C. Downes. New York: Charles Scribner's Sons, 1940.

GOEBEL, B.. Rectitudo. Wahrheit und Freiheit bei Anselm von Canterbury. Eine philosophische Untersuchung seines Denkansatzes. Münster: Aschendorff, 2001.

HENDLEY, B. Anselm's Proslogion Argument. In: KLUXEN, W. (Hrsg.). Miscellanea Mediaevalia 13/2 - Sprache und Erkenntnis im Mittelalter. Berlin: Walter de Gruyter, 1981, p. 838-846.

HENRY, D. P. The Logic of Saint Anselm. Oxford: Oxford University Press, 1967 (repr. 1993). 
HOGG, D. S. Anselm of Canterbury. The Beauty of Theology. Aldershot: Ashgate, 2004.

HOPKINS, J.. A Companion to the Study of St. Anselm. Minneapolis: University of Minnesota Press, 1972.

Anselm of Canterbury (1033-1109). In: CRAIG, E. (ed.). The Routledge

Encyclopedia of Philosophy. London - New York: Routledge, 1998, p. 283-297.

HOPKINS, J. and RICHARDSON, H.. Introduction. In: CANTERBURY, A. O.. Truth, Freedom, and Evil - Three Philosophical Dialogues. Edited and translated by Jasper Hopkins and Herbert Richardson. Toronto - New York: The Edwin Mellen Press, Vol. II, 1976, p. 10-85.

. Notes. In: CANTERBURY, A. O.. Truth, Freedom, and Evil - Three Philosophical Dialogues. Edited and translated by Jasper Hopkins and Herbert Richardson. Toronto - New York: The Edwin Mellen Press, Vol. II, 1976, p. 226237.

KAPRIEV, G.. ... Ipsa vita et veritas. Der "ontologische Gottesbeweis" und die Ideenwelt Anselms von Canterbury. Leiden - Boston - Köln: Brill, 1998.

KING, P.. Anselm's Philosophy of Language. In: DAVIES, B. and LEFTOW, B. (eds.). The Cambridge Companion to Anselm. Cambridge: Cambridge University Press, 2004, p. 84-110.

KOHLENBERGER, H.. Similitudo und Ratio. Überlegungen zur Methode bei Anselm von Canterbury. Bonn: Bouvier Verlag - Herbert Grundmann, 1972.

MCGILL, A. C. Recent Discussions of Anselm's Argument. In: HICK, J. and MCGILL, A. C. (eds.). The Many-Faced Argument. Recent Studies on the Ontological Argument for the Existence of God. London - Melbourne: MacMillan, 1968, p. 33-110.

MOREAU, J.. Logique et dialectique dans l'argument du "Proslogion". In: KLUXEN, W. (Hrsg.). Miscellanea Mediaevalia 13/2 - Sprache und Erkenntnis im Mittelalter. Berlin: Walter de Gruyter, 1981, p. 718-723.

POUCHET, R.. La rectitudo chez Saint Anselme. Un itinéraire Augustinien de l'ame à Dieu. Paris: Études Augustiniennes, 1964.

RIBEIRO, E. S.. O argumento epistemológico de Anselmo. Porto Alegre: PUCRS (Dissertação de Mestrado), 2006.

SCHMITT, F. S.. Einführung. In: CANTERBURY, A. O.. De veritate - Über die Wahrheit. Latenisch-Deutsche Ausgabe von P. Franciscus Salesius Schmitt O.S.B. Stuttgart - Bad Cannstatt: Friedrich Frommann Verlag (Günther Hozboog), 1966, p. 7-29. 
. Einführung. In: CANTERBURY, A. O.. Proslogion. Latenisch-Deutsche Ausgabe von P. Franciscus Salesius Schmitt O.S.B. Stuttgart - Bad Cannstatt: Friedrich Frommann Verlag (Günther Holzboog), 1961 ( $\left.{ }^{3} 1995\right)$, p. 9-65.

SCHÖNBERGER, R.. Anselm von Canterbury. München: Verlag C. H. Beck, 2004. SHANON, D.l E. Hegel Facing Anselm's God, Evil, and Truth. In: FORTIN, J. R. (ed.). Saint Anselm - His Origins and Influence. Lewiston - Queenston - Lampeter: The Edwin Mellen Press, 2001, p. 161-182.

SYNAN, E. A. Truth: Augustine and Anselm. In: SCHNAUBELT, J. C. et alii (eds.). Anselm Studies. An Occasional Journal. White Plains (N. Y.): Kraus International Publications, 1988, p. 275-295

VISSER, Sandra and WILLIAMS, Thomas. Anselm on Truth. In: DAVIES, B. and LEFTOW, B. (eds.). The Cambridge Companion to Anselm. Cambridge: Cambridge University Press, 2004, p. 204-221.

E-mail: rhpich@pucrs.br

Recebido: novembro/2009 Aprovado: dezembro/2009 